九州大学学術情報リポジトリ

Kyushu University Institutional Repository

Comparative morphology and phylogeny of the superfamily Curculionoidea of Japan (Comparative morphology, phylogeny and systematics of the superfamily Curculionoidea of Japan. I)

Morimoto, Katsura

Entomological Laboratory, Department of Agriculture, Kyushu University

https://doi.org/10.5109/22690

出版情報: 九州大学大学院農学研究院紀要. 11 (4), pp.331-373，1962-03. Kyushu University バージョン：

権利関係 : 
Journal of the Faculty of Agriculture, Kyūshū University, Vol, 11, No. 4

March 31, 1962

Comparative morphology and phylogeny of the superfamily Curculionoidea of Japan

(Comparative morphology, phylogeny and systematics of the superfamily Curculionoidea of Japan. I)

\section{Katsura MORImoto}

The superfamily Curculionoidea is an immense group of the order Coleoptera comprising more than 40000 species from the world. Since the description of Amblycerus japonicus by Thunberg in 1815 Japanese species have been studied by many authorities, and about 1000 species are known at present. But, it is doubtful whether this number represents even half of those existing to-day in Japan.

For these nine years I have been studying the superfamily Curculionoidea at the Entomological Laboratory of Kyushu University under the guidance of the late Prof. Teiso Esaki, Prof. Keizô Yasumatsu and Prof. Yoshihiro Hirashima.

My first question arose about the classification of the higher categories of the Curculionoidea, which have very of ten been characterized by a few structures. It is presumable to me that these systems have of ten been affected by the general appearance or the first impression of the shapes of weevils. In spite of the development of the morphology and ethology, only a slight development of the system has been brought to the systematic of the group for a century since Lacordaire (1863, $66)$.

In this paper I exert myself to set forth the phylogenetic system of the Curculionoidea basing on the knowledge of the comparative morphology of the materials obtained in Japan. I am well conscious of the insufficiency of materials, but it is strongly hoped that many knowledge will be added and the system will be reconstituted by a number of authorities in the various countries of the world.

I acknowledge my indebtness to the late Prof. Esaki, Prof. Yasumatsu and Prof. Hirashima, without whose guidance I could not complete this work.

Contribution Ser. 2, No. 120. Entomological Laboratory, Kyushu University. 
I have also to express my tharks to the following gentlemen for their kindness on material and literature:-Dr. K. Baba, Prof. M. Châjô, Messrs. T. Hidaka, S. Hisamatsu, H. Ichihashi, Y. Ikezaki, R. Ishikawa, H. Kamiya, T. Kawarabata, K. Kawashima, S. Kimoto, Prof. K. Kojima, Dr. M. Konishi, Dr. H. Kôno, Dr. Y. Kurosawa, Y. Maeta, K. Matsuda, Pr of. S. Miyamoto, M. Miyatake, Y. Miyatake, Dr. Y. Murakami, J. Nagao, Prof. S. Nakao, Prof. T. Nakane, T. Saigusa, K. Shirahata, Prof. T. Shirôzu, M. Sonda, M. Takahashi, Prof. Y. Takenouchi, Dr. S. Uéno, Dr. E. Voss, Miss. R. E. Warner, H. Yamamoto and K. Yano.

\section{HEAD}

\section{General shape.}

The most obvious character of the Curculionoidea is the beak or rostrum. It is very variable in development and often even absent. With a few exceptions gula has entirely disappeared and there is only a single median suture. The length and shape of the rostrum are often correlated with the oviposition behaviour.

Rostrum may fundamentally be straight and directing anteriorly. In accordance with the development of rostrum it requires special movement and power to drill the ovipositing hole. In Attelabidae and some Brenthidae head is rather long and often it is prolonged into a short neck behind eyes, and the necked head is suited to the drilling movement of rostrum. In the remaining families head is principally globular and rostrum is directed downwards, and the head is suited to increase the drilling power and rotatory movement in the prothoracic cavity.

\section{Antennae.}

The fundamental number of segments in antennae is 12 , but the terminal segment is usually indistinct and very often indistinguishable.

There are two well-known types, namely, geniculate or straight. Kolbe (1901) divided the Curculionidae into two groups using these characters as Curculionidae Orthoceri and Curculionidae Gonathoceri. As a rule, weevils bearing straight antennae may be said more primitive than those bearing geniculate ones.

Scape is usually short in straight antennae, more or less longer in geniculate ones. Development of the scape, scrobes and rostrum may be correlated to the feeding or drilling movement. It is, therefore, desirable to review these characters from the standpoint of the comparative ethology.

Funicle normally comprises 7 segments, the number varying from 


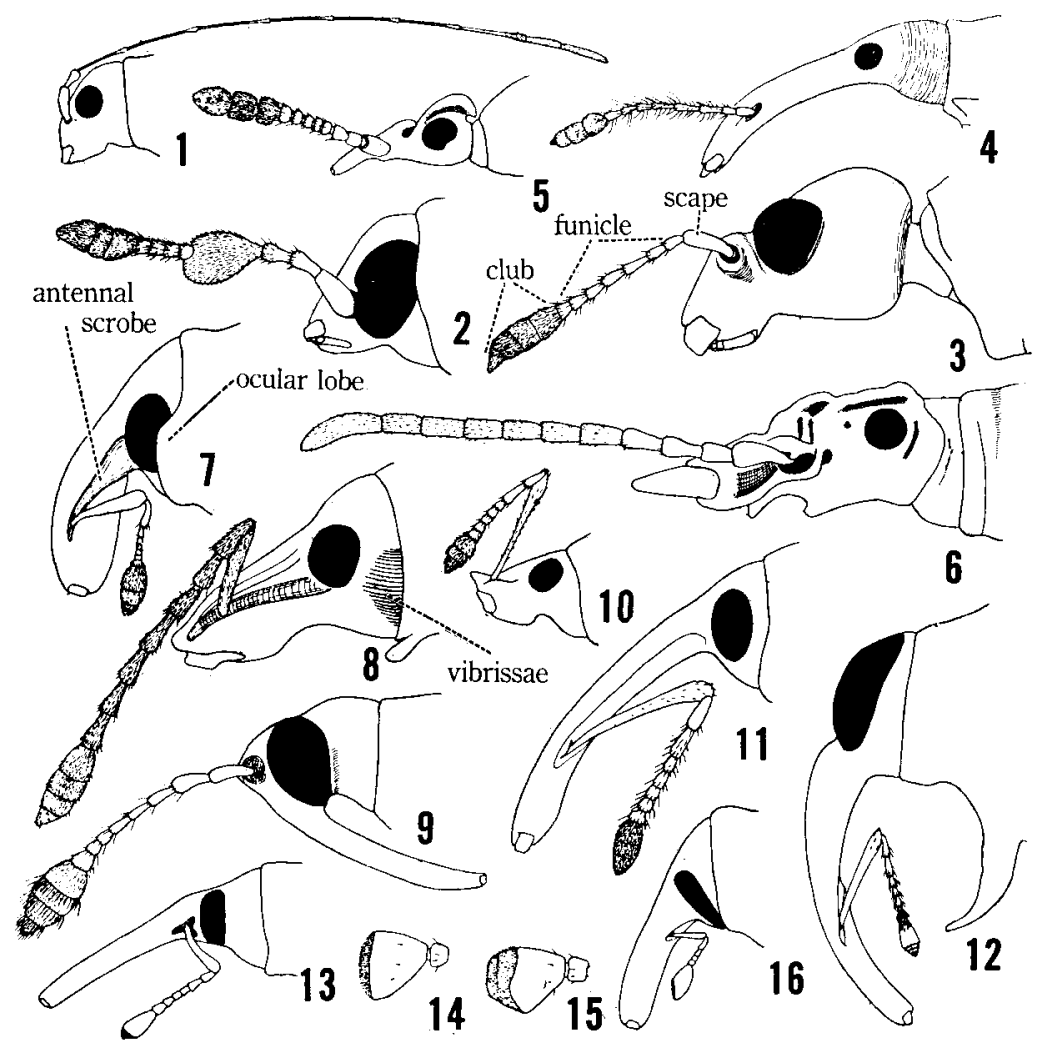

Fig. I. Head and antenna of :

1. Apolecta lewisii, 오; 2. Ozotomerus japonicus, ô; 3. Paroplapoderus pardalis, 우.; 4. Rhynchites heros, ô; 5 . Higonius cilo, ô; 6. Baryrrhynchus poweri, $\overrightarrow{0}$; 7. Bagous kagiashi, 9 ; 8. Chlorophanus grandis, 3 ; 9. Rhamphus pullus, 우 ; 10. Anosimus decoratus, of; 11. Notaris okunii, $q$; 12. Phylaitis maculiventris, $\Varangle ; 13$. Diocalandra elongata, 우 ; 14. Otidognathus jansoni, antennal club; 15 . Aplotes roelofsi, antennal club; 16. Dryophthorus sulcatus, 우.

4 to 8 , terminal segment is often annexed to club.

Club is fundamentally composed of 4 segments, often 3 in the groups having 11-segmented antennae. It is generally pubescent very closely. Club is not developed in some Brenthidae and loosely segmented in some Anthribidae, Attelabidae and some Brenthidae. It is compact and visibly one-segmented in some Scolytidae and some Cryptorrhynchinae. In Rhynchophoridae the basal segment is fully developed and polished. In Dryophthorus and Dryophthoroides the pubescent portion is entirely flat. Marshall (1916) described that the pubescent segments of club are telescoped into the basal polished one, but the formers are 
apparently shortened, compact and not telescoped judding from the dissected examination.

\section{Mouth parts.}

Mouth parts of the Curculionoidea were studied by Ting (1936). The terms used here are followed after him.

\section{Labrum}

Labrum is present only in Anthribidae (also in Rhinomaceridae after Ting, 1936, and Crowson, 1955), and absent in the other families.

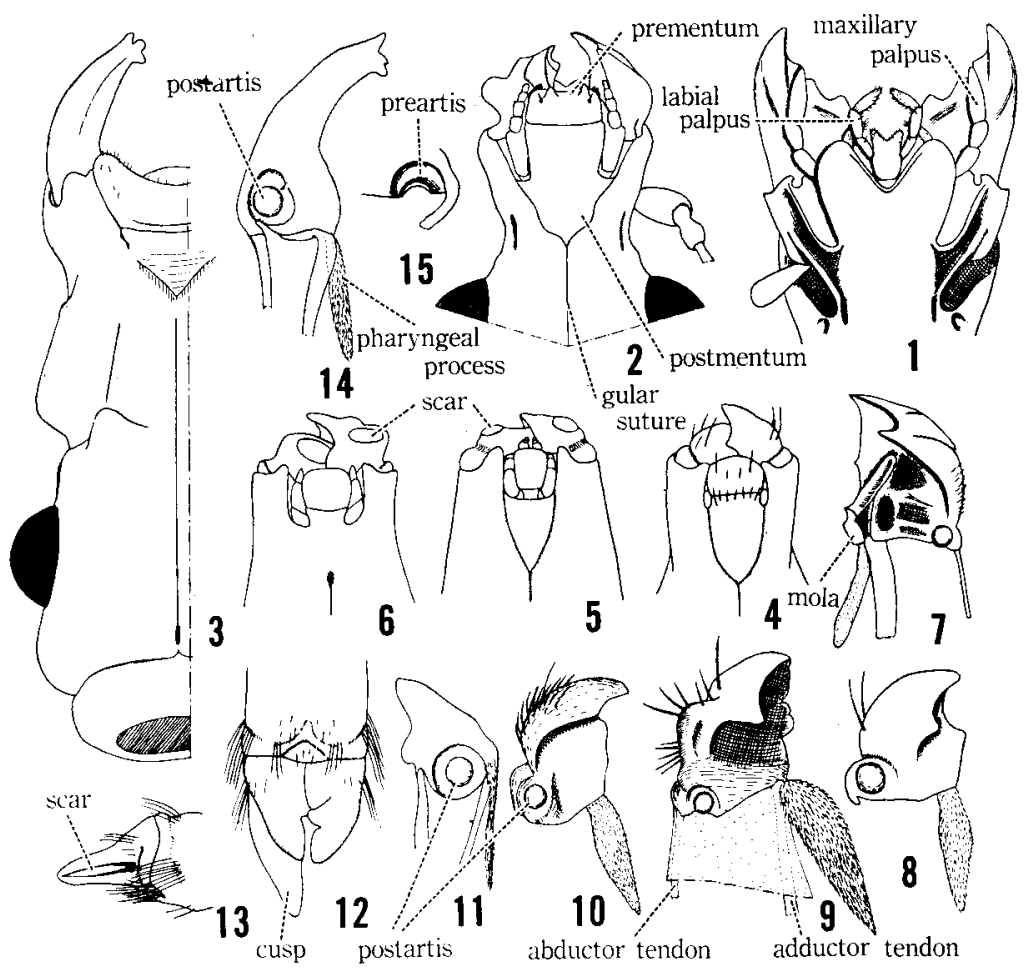

Fig. II. Mouth parts, ventral aspect, and mandibles of :

1. Tropideres germanus; 2. Apoderus balteatus; 3. Baryrrhynchus poweri; 4. Pachyrrhynchus infernalis; 5. Scythropus scutellaris; 6. Arrhaphogaster pilosus; 7. Euparius oculatus, left ventral; 8. Pachyrrhynchus infernalis, right ventral; 9. Galloisia inflata, right ventral; 10. Eugnathus distinctus, right ventral; 11. Curculio arakawai, right ventral; 12. Desmidophorus crassus, apex of rostrum, dorsal aspect, right mandible bearing a cusp; 13. id., lateral aspect, showing a narrow scar; 14. Baryrrhynchus poweri, right ventral; 15 . id., right dorsal, showing preartis. 


\section{Mandibles}

The preartis of mandible consists of a semi-circular, convex ball surrounded by a trough-like acceptabulum. The crescent shaped rim of precoila fits into the acceptabulum.

The postartis of mandible consists of a subglobular ball only and

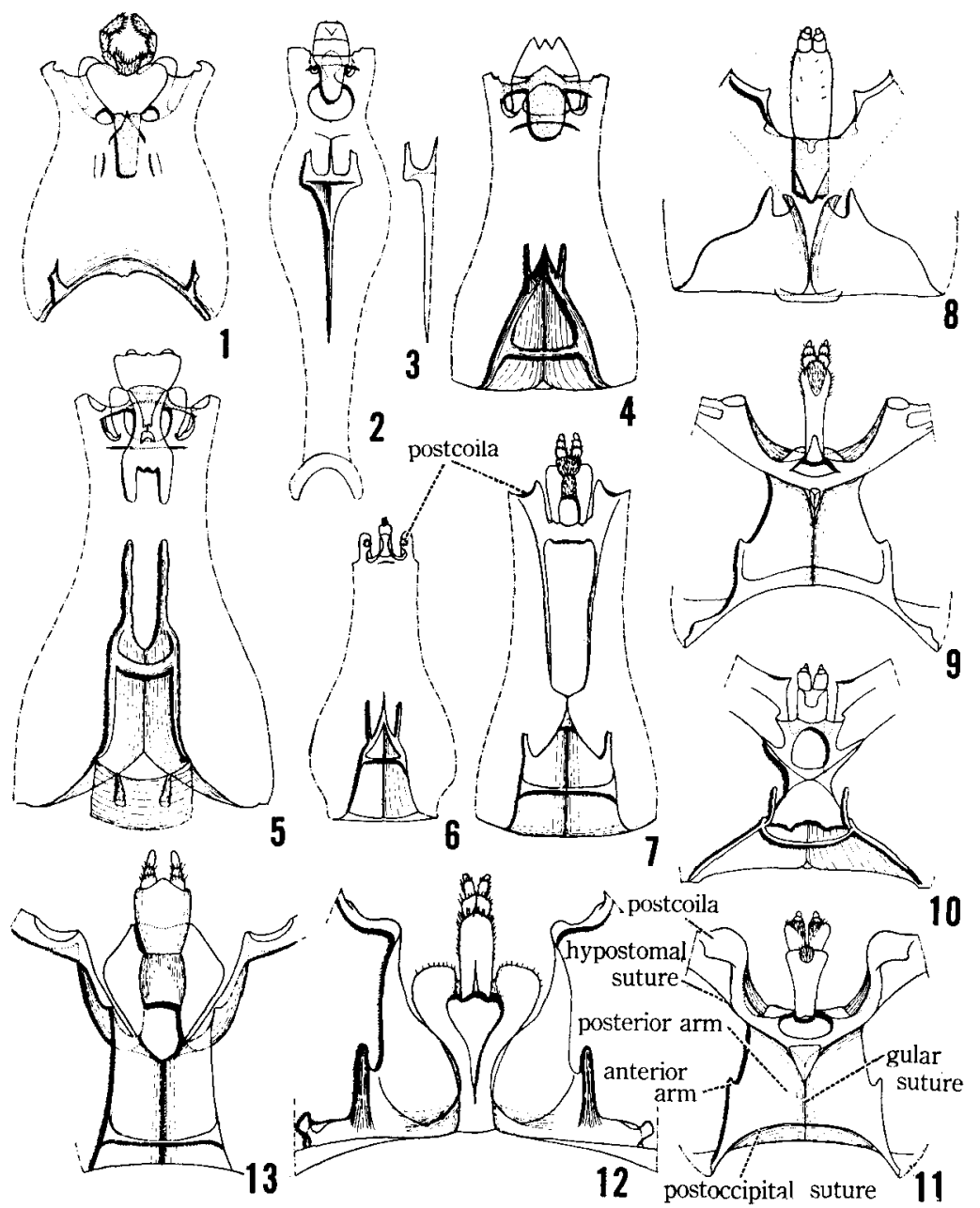

Fig. III. Tentorium and mouth parts, dorsal aspect, of :

1. Tropideres germanus; 2. Paratrachelophorus longicornis, 3 ; 3. id., tentorium, lateral aspect; 4. Euops splendida; 5. Phialodes rufipennis; 6. Eugnamptus amurensis; 7. Byctiscus princeps; 8. Scolytoplatypus mikado; 9. Ips typographus; 10. Hylurgops interstitialis; 11. Xyleborts validus; 12 . Crossotarsus nipponicus; 13 . Platypus modestus,. 
fits into the concave acceptabulum of the postcoila of rostrum. The postcoila is shallow dish-shaped and located on the anterior margin of the postgenal area, into which the ball of postartis fits not strongly in

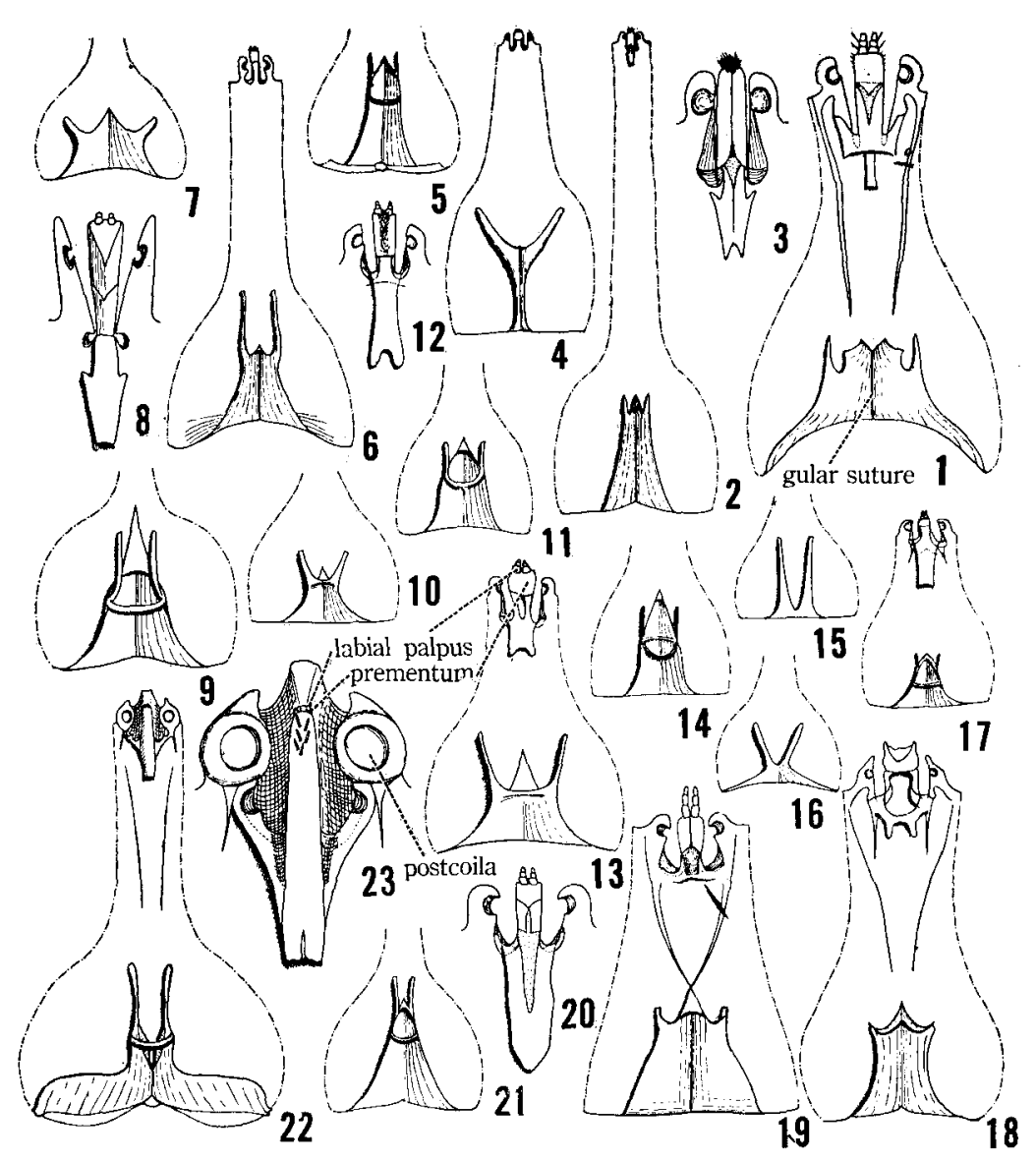

Fig. IV. Tentorium and mouth parts, dorsal aspect, of :

1. Desmidophorus crassus; 2. Baryrrhynchus poweri, 우; 3. id., mouth parts, enlarged; 4. Apion sp.; 5. Cylas formicarius; 6. Nanophyes japonicus; 7. Metialma japonica; 8. Curculio dentipes, mouth part ; 9. id., tentorium; 10. Hypera nigrirostris; 11. Mecyslobus piceus; 12. id., mouth part; 13. Trichalophus albonotatus; 14 . Hylobius elongatus; 15. Anthonomus bisignifer; 16. Rhinoncus sibiricus; 17. Cossonus gibbirostris; 18. Lixus acutipennis; 19. Phyllobius armatus; 20. Shirahoshizo insidiosus, mouth part; 21. id., tentorium; 22. Hyposipalıs gigas; 23. id., mouth part, enlarged. 
Anthribidae, Attelabidae, Scolytidae and Platypodidae. In the other families the postcoila is deeper and lying on the postgenal arm a little behind the anterior margin. It is often said that Scolytidae is close to some Cossoninae in systematic position, but the postcoila is different.

There are mandiblular scars on the mandibles of Otiorrhynchinae and Desmidophorus, and the edge of the scar is always slightly raised above the adjoining surface of the mandible. This structure called mandibular scar serves as a support for a deciduous cusp, which in most species of these groups normally breaks off soon after the emergence of the adult from the pupal chamber in the soil (life history of Desmidophorus is unknown), though persisting in a few individuals. According to Buck (1952), the Rhynchitinae excluding Auletini investigated by him bear deciduous appendages on the outer surface of mandibles of a newly emerged adult. The deciduous cusp is morphologically a part of mandible itself judging from the observation of the pupa.

The mola is well developed in the mandibles of Anthribidae and less developed in Scolytidae. According to Ting (1936) it is distinct and proportionally smaller in Rhinomacer than in Anthribidae.

The mandible bears a pharyngeal process at the inner basal angle, which is known to belong to the pharhyngeal wall and not the mandibular appendage. Pharyngeal process is extremely long in Rhynchophoridae excepting Dryophthorus and Dryophthoroides, and very short or vestigial in Scolytidae and Platypodidae.

Mandibles move horizontally in Anthribidae and Attelabidae, nearly horizontally with their cutting or gouging action slightly upwards in the other families, while in Curculio the mandible moves vertically.

\section{Maxillae}

Maxilla consists fundamentally of cardo, stipes, lacinia, galea, palpiger and palpus. All parts are observed in Anthribidae, Attelabidae, Platypodidae and Sitoninae. The region of lacinia becomes fused with galea and is forming mola in the other groups. Palpi are 4-segmented in Anthribidae and Attelabidae, 3-segmented in the other families.

Maxillae move in a horizontal plane in Anthribidae and Attelabidae, nearly horizontally in Scolytidac and Platypodidae, and vertically in Brenthidae, Curculionidae and Rhynchophoridae.

\section{Labium}

Curculionoidea may be separable from the other Coleoptera by the structure of labium. Labium of most of the Coleoptera is divided into three regions known as prementum, mentum and submentum, whereas in the Curculionoidea mentum has become fused with submentum, so that there are two distinct regions present, which are designated as prementum and postmentum. 


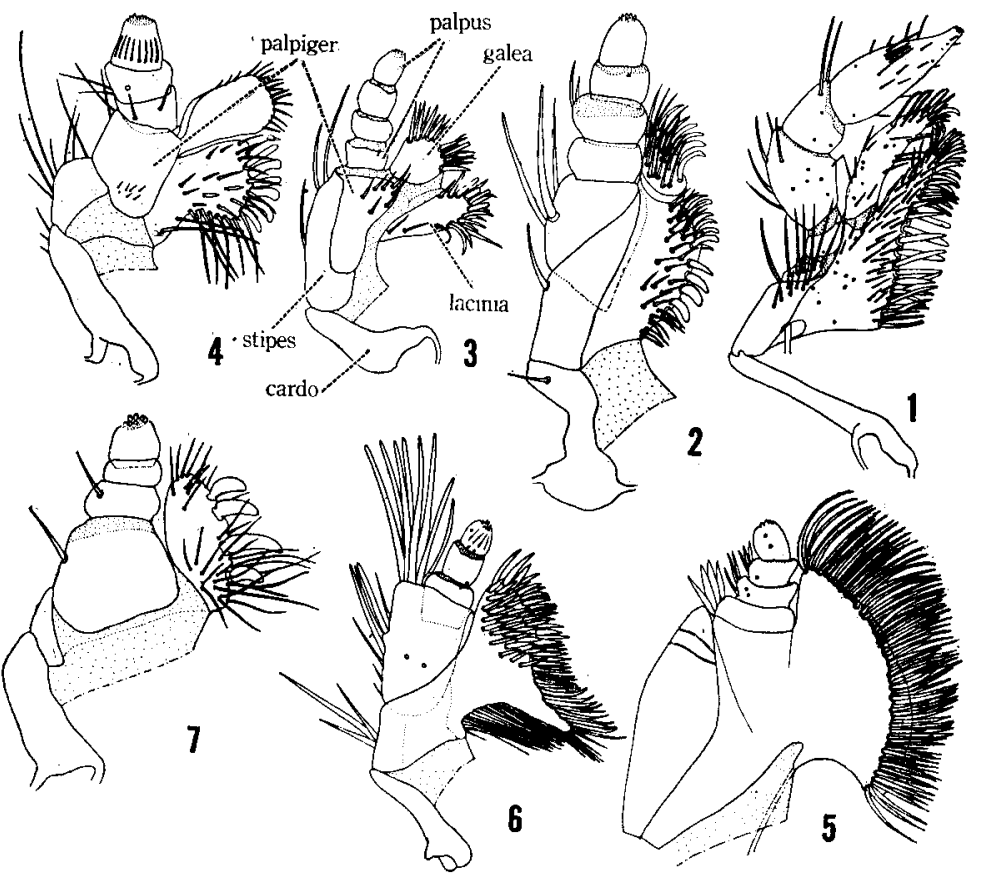

Fig. V. Maxilla of :

1. Araecerus fasciculatus; 2. Mecorhis ursulus; 3. Henicolabus lewisii; 4. Sitona japonica; 5. Curculio arakawai, cardo removed; 6. Desmidophorus crassus; 7. Nanophyes japonicus.

Lacordaire (1863) divided the Curculionidae into Curculionidae Adelognathi and Curculionidae Phanerognathi utilizing the relative position of the prementum and postmentum to the other parts of the mouth. In the Adelognathi, the large and pincer-shaped mandibles occupy the greater part of the preoral cavity and the smaller space left behind them is almost concealed by the prementum, and the postmentum is not pedunculate, while in the Phanerognathi the postmentum is more or less pedunculate and the prementum is not covering the whole preoral cavity left behind mandibles.

Primarily labial palpi may be 3 -segmented and attached to the ventral surface of the prementum as observed in Anthribidae. In accordance with the development of rostrum accompanying the drilling movement, labial palpi are translocated in the majority of the Curculionoidea to the anterior margin of prementum, or the palpi are shortened and inserted into the cavities on the ventral surface of the prementum as in Attelabinae, Cleoninae and Eugnathus. Labial palpi are 3-segmented in the majority of the Curculionoidea, 2-segmented in Phialodes, Cylas, some Brenthinae, Nanophyes, Curculio, Episomus, Amystax and Blosyrus, one- 
segmented in the majority of Attelabinae, Apioninae, Cleoninae and the majority of Rhynchophoridae, palpi are absent in Euops and Galloisia.

In Rhynchophoridae the prementum is reduced and deeply retructed into the oral cavity and invisible from underside, while in the other families it takes normal position and freely visible from below.

The dorsal surface of the postmentum is deeply excavated in Attelabidae, majority of Scolytidae and Platypodidae.

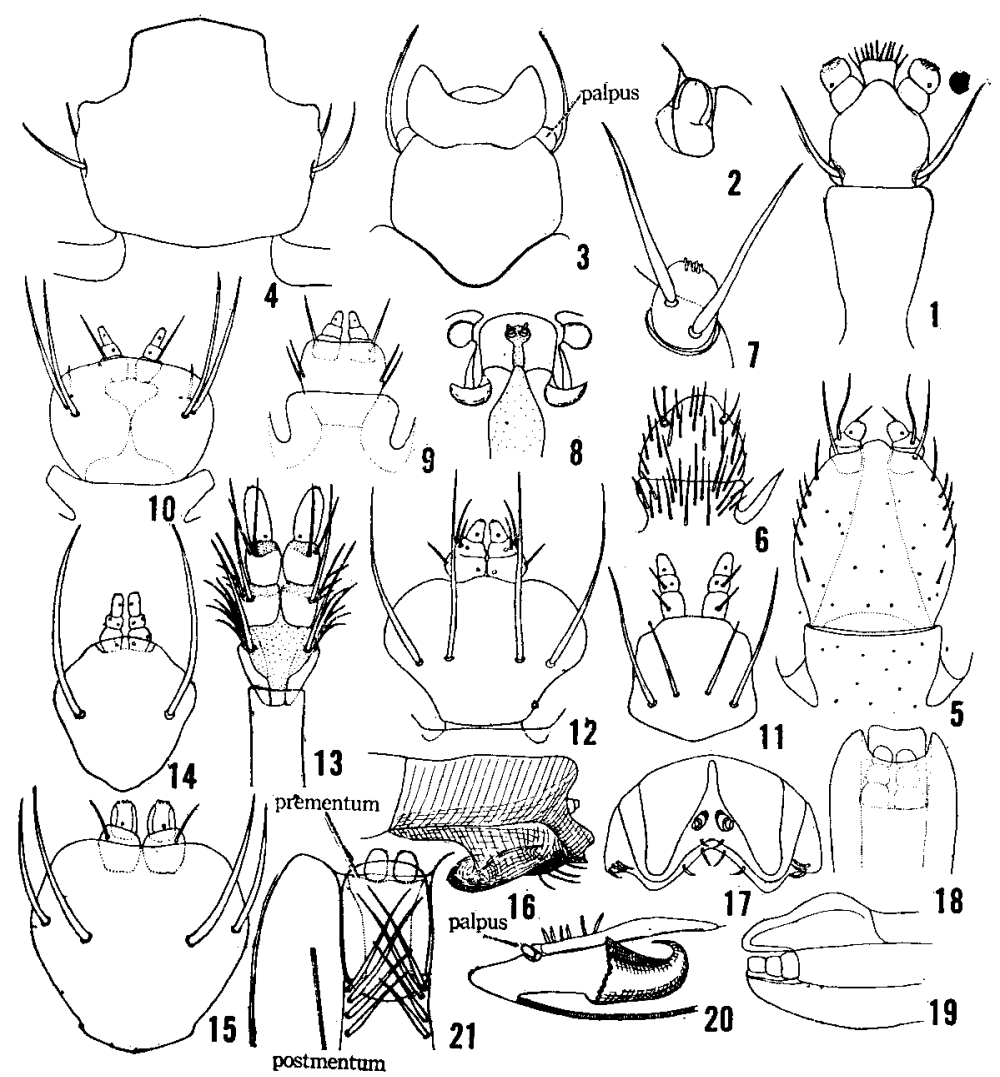

Fig. VI. Labium of :

1. Nanophyes japonicus; 2. Cylas formicarius, palpus, dorsal aspect; 3 . Lixus impressiventris; 4. Galloisia inflata; 5 . Sitona japonica; 6. Eugnathus distinctus; 7. id., palpus enlarged; 8. Pachyrrhynchus infernalis, dorsal aspect; 9. Trichalophus albonotatus; 10. Byrsopages sp.; 11. Myllocerus griseus; 12. Cyrtepistomus castaneus; 13 . Mecopomorphus griseus; 14 . Calomycterus setarius; 15 . Amystax fasciatus; 16 . Episomus turritus; prementum, lateral aspect; 17. id., frontal aspect; 18. Diocalandra clongata; 19. id., lateral aspect; 20. Hyposipalus gigas, lateral aspect; 21 . Aplotes roelofsi, dorsal aspect. 
In Anthribidae preoral cavity is completely divided by a transverse wall, so that mandibles are separated from prementum and maxillae excepting their apical parts. The corium of maxillae reaches the pharynx through the openings in the transverse wall which allows the base of the cardos and their tendons to protrude. The dorsal membraneous surface of the postmentum apparently becomes sclerotized and fused to the ventral surface of the transverse wall. There is a small median opening in the transverse portion which allows the tendons of the lacinia to extend into the head capsule.

Somewhat similar structures are observed in Attelabinae, there is

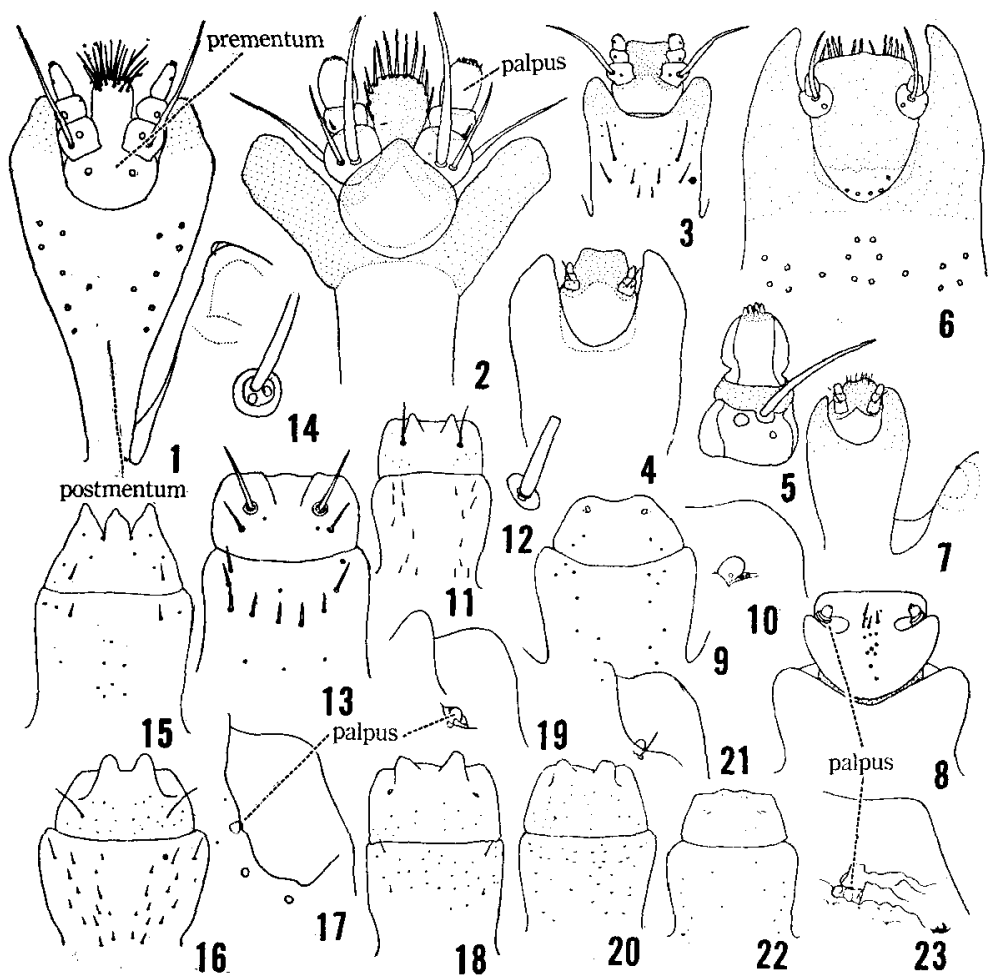

Fig. VII. Labium of Attelabidae:

1. Aderorhinus crioceroides; 2. Mecorhis ursulus; 3. Byctiscus venustus; 4. Chonostropheus chujoi; 5. id, palpus en]arged; 6. Chokkirius truncatus; 7. Deporaus unicolor; 8. Phialodes rufipennis; 9. Henicolabus lewisii; 10. id., palpus enlarged; 11. Paroplapoderus pardalis; 12. id., palpus enlarged; 13. Himatolabus cupreus; 14. id., palpus enlarged; 15. Euops splendida; 16 . Phymatapoderus pavens; 17 . id., palpus enlarged ; 18. Paratrachelophorus longicornis; 19. id., palpus enlarged; 20. Paracentrocorynus nigricollis; 21. id, palpus enlarged; 22. Cycnotrachelus nitens; 23. id., palpus enlarged. 
a transverse bridge connecting the pregenal areas behind the postcoilae and pharynx. The transverse bridge is sclerotized in Apoderini and less sclerotized in Attelabini and Euopsini.

\section{Tentorium.}

In the Curculionoidea, with a few exceptions, gula has entirely disappeared and there is only a single median suture, and the head is more or less protruded anteriorly and forming the rostrum. In connection with these characters the tentorium of the head of Curculionoidea differs from the normal Coleoptera having a distinct gula.

Tentorium of the Curculionoidea may be divided into the following four types. In any types anterior tentorial arms are reduced to threads and median parts of the armes are easily melted away when head is boiled in $\mathrm{KOH}$ solution.

i. Anthribid-type.

Tentorial bridge is incomplete and posterior arms are reduced to a pair of small processes, posterior tentorial pits are located on the postoccipital suture.

\section{ii. Curculionid-type.}

Tentorial bridge is narrow or incomplete, posterior tentorial arms are very broad, originated from the gular suture and ventral part of postoccipital suture, subtriangular from dorsal aspect, base of anterior arm originates before the middle of posterior arm from dorsal aspect. Anterior parts of the posterior armes are often inflected inwards, conglutinate the margins to each other and forming a conical sack.

This type is observed in Attelabidae (excluding Apoderini), Brenthidae and Curculionidae. In several genera dissected such as Anthonomus, Orobitis, Rhinoncus, and Rhynchaenus the posterior arms originate mostly from the postoccipital suture and the ventral part of the pits is short. In several genera dissected such as Hypera, Hylobius and Trichalophus, there is a transverse ridge between the base of anterior arms. In Apion the tentorium is $Y$-shaped from dorsal aspect, posterior arms originate mostly from gular suture and very narrowly from postoccipital suture.

iii. Apoderine-type.

In the tribe Apoderini the posterior arms of tentorium originate only from the gular suture and the pits are far remote from the postoccipit. Tentorial bridge is absent.

iv. Scolytid-type.

In Scolytidae and Platypodidae the tentorial bridge is either complete or incomplete, posterior arms originate from the postoccipital suture, gular suture and hypostomal suture. Therefore, the posterior arms are forming the broad longitudinal bands from dorsal aspect.

It is presumable to me that the above mentioned types of tentorium 
may be differentiated in the following way.

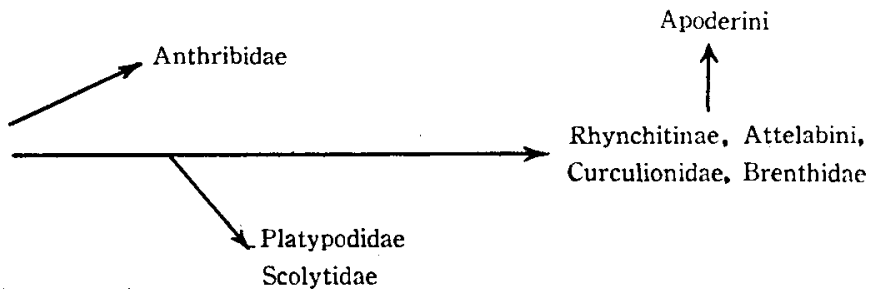

\section{THORAX}

\section{Prothorax.}

Leconte (1867) gave a definition of Rhynchophora including a character of prothorax, of which the dorso-lateral suture is always absent. According to Marshall (1916) only the exceptions are found in Oxycorynus and Pterocorynus, in which the dorso-lateral suture is well defined. Pleurosternal suture is complete in Brenthinae and Ithycerinae, well developed but not reaching the anterior margin of prothorax in Apioninae, and short or indistinguishable in the other groups. In Anthribidae, Attelabidae and Nanophyinae the short sutures prolong laterally, but those are strongly oblique or directing anteriorly in the other groups.

Prosternum is divided into basisternum and sternellum by a faint transverse suture.

Coxal cavities are often contiguous and often separated, in Platypodidae conjoint cavities are very large and reaching the posterior margin of prothorax.

Ocular lobes and vibrissae are often observed on the lateral sides of prothorax behind eyes, presence or absence of these structures afford a good systematic character.
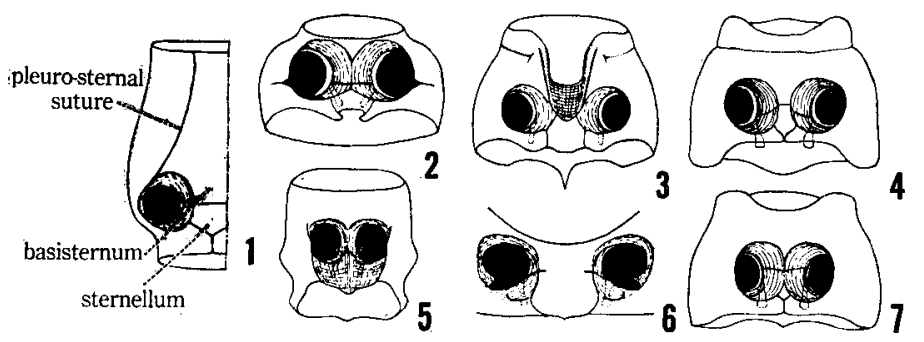

Fig. VIII. Prosternum (coxae removed) of :

1. Baryrrhynchus poweri; 2. Phialodes rufipennis; 3. Mecysmoderes fulvus; 5. Platypus modestus; 6. Scolytoplatypus mikado; 7. Hylobius abietis haroldi. 
Prosternum is often depressed for the reception of rostrum in repose in various groups of Brenthidae, Scolytidae and Curculionidae.

\section{Mesothorax.}

Episterno-sternal suture is often indistinguishable in various groups. Mesepisterna are separated from elytra by mesepimera. In apterous weevils, however, mesepimera are often very small and mesepisterna are broadly contiguous with elytra. In Cylas mesepimera are entirely concealed under elytra. Mesepimera are larger and strongly ascended upwards between the humeri of elytra and the basal angles of pronotum in Barinae, Ceuthorrhynchinae and some Zygopinae.

\section{Metathorax.}

Posterior part of metepimera are exposed in Anthribidae, Attelabidae and various groups of the other families. Metasternum has a longitudinal median suture in Anthribidae, Attelabidae, Platypodidae, Scolytidae and in various groups of the other families.

Metasternum is often very short in the apterous weevil.

\section{Metendosternite.}

Metendosternite of Coleoptera was extensively studied and excellent results were obtained by Crowson $(1938,1944)$. It is very difficult to presume the relationship within the Curculionoidea from the structure of metendosternite only, but this is often very important to designate the group of weevils.

Following is the result of my investigation of the metendosternite.

i. In such primitive groups as Anthribidae, Attelabidae and Brenthinae the furca has the anterior tendons narrowly separated and the stalk is slenderer, in Cylas, Apion and Nanophyes the anterior tendons are a little more separated than in those groups and having the similar stalks.

ii. In major Curculionidae, Rhynchophoridae, Scolytidae, Ithycerus and Desmidophorus metendosternite has long furcal and lateral arms and short stalks.

iii. In the adelognathous Curculionidae the furcas are fully applied for the designation of the tribes in the chapter of systematics.

iv. In Platypodidae the furca is Y-shaped, the dorsal and ventral surfaces excepting the apex of furcal arms are flat, the anterior tendons are very delicate and narrowly separated.

v. In some apterous Curculionidae Phanerognathi and Rhynchophoridae such as Seleucha, Protacalles, Otibazo, Cotasteromimus, Pseudoporopterus, Tetratemnus and Dryophthoroides the lateral arms of the furca are reduced 
or absent.

vi. In some apterous Curculionidae Adelognathi such as Catapionus, Dermatoxenus and Callirhopalus the furca has the anterior tendons broad and the ventral muscles of metathorax are inserted into the bases of mesofurca or mesocoxal bowls a little behind the base of mesofurca. These muscle arrangement may be possible by the reduction of the tergo-sternal muscles of the metathorax.

vii. In Blosyrus japonicus the metafurca is directly conglutinate to

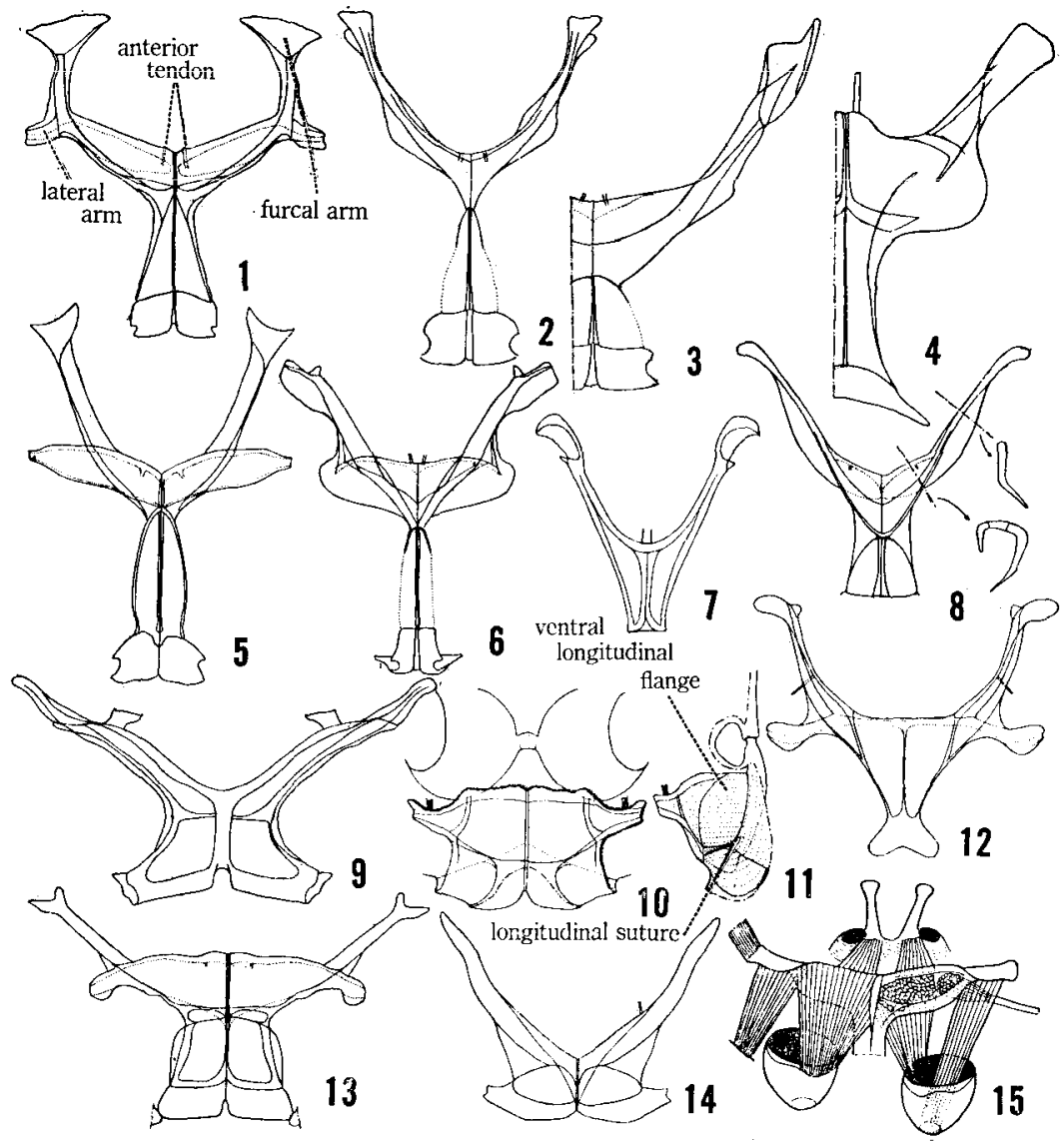

Fig. IX. Metendosternite of :

1. Araecerus fasciculatus; 2. Apion placidum; 3. Nanophyes japonicus;

4. Baryrrhynchus poweri; 5. Mecorhis ursulus; 6. Phialodes rufipennis;

7. Platypus modestus; 8. Cylas formicarius; 9. Byrsopages sp.; 10.

Isonycholipus gotoi. 11. id, lateralaspect; 12. Scolytoplatypus mikado;

13. Larinus ovalis; 14. Dryophthorus americanus; 15. Dermatoxenus caesicollis, musculature. 
the mesocoxal bowls in two points, to which the ventral muscles are inserted in the case of Dermatoxenus. This may be a peculiar case of the reduction of the ventral muscle.

viii. In Pachyrrhynchus and Isonycholips the ventral longitudinal flange of the furca is strongly developed and conglutinate to the median longitudinal line of metasternum in whole length.

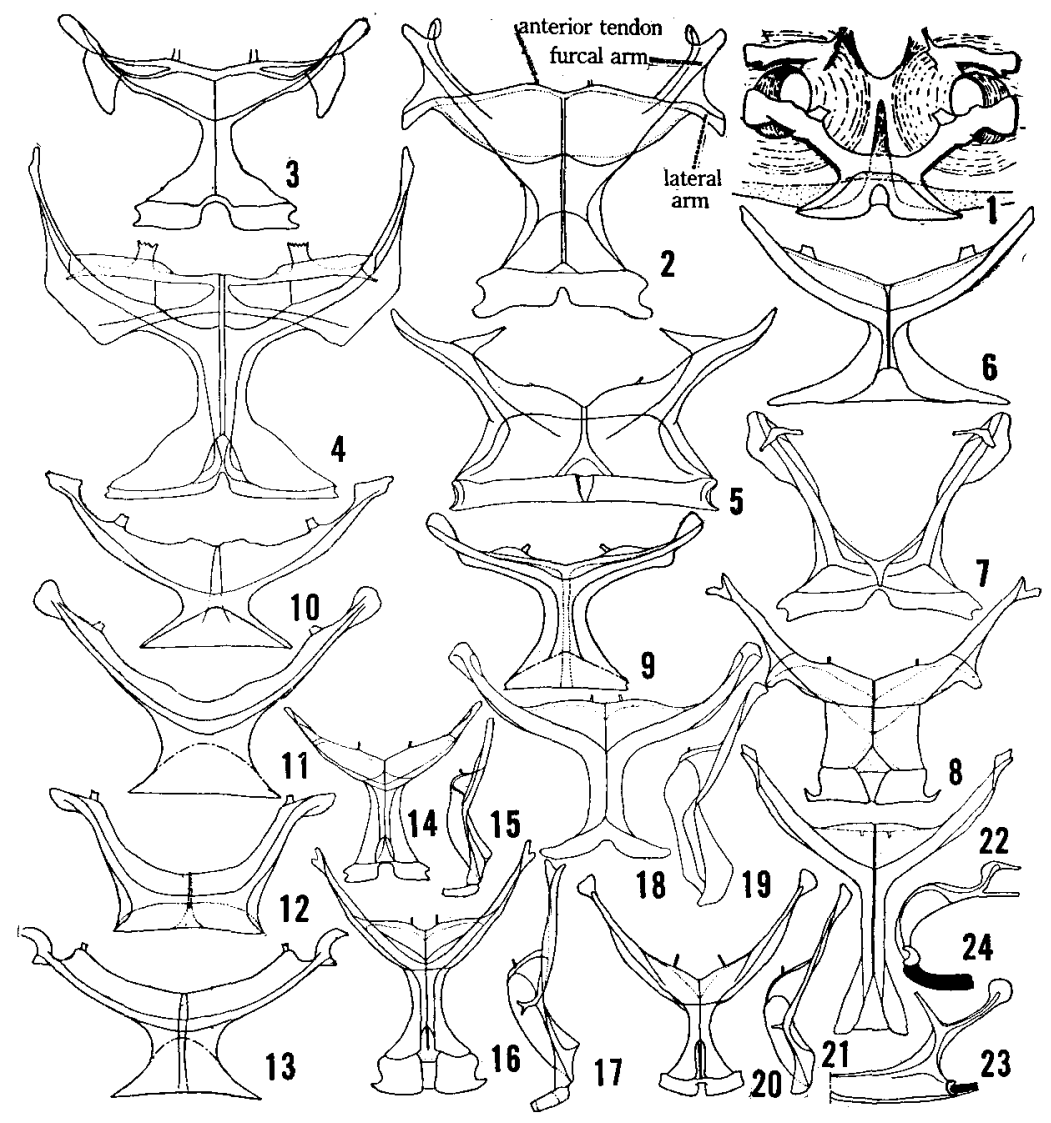

Fig. X. Metendosternites of Curculionidae adelognathi:

1. Pachyrrhynchus infernalis; 2. Chlorophanus grandis; 3. Episomus turritus; 4. Dermatoxenus caesicollis; 5. Scepticus sp.; 6. Callirhopalus bifasciatus; 7. Amystax fasciatus; 8. Eugnathus distinctus; 9. Myosides seriehispidus; 10. Otiorrhynchus sulcatus; 11. Trachyphloeosoma sp.; 12. Asphalmus japonicus; 13. Trachyrhinus sp.; 14. Calomycterus setarius, 15. id., lateral aspect ; 16. Myllocerus griseus ; 17 . id., lateral aspect; 18. Scythropus ornatus; 19. id., 1ateral aspect ; 20. Cyphicerus tosanus ; 21. id., lateral aspect; 22. Phyllobius rotundicollis; 23. Arrhapogaster pilosus, right half; 24., lateral aspect. 
LEGS

\section{Trochanters.}

Trochanters of the Curculionoidea are small and triangular, bases of femora are close to coxae excepting the Apioninae, of which the large trochanters are intervened between femora and coxae.

\section{Femora.}

Femora are usually more or less clavate in the distal half, frequently bearing a tooth on the undersurface, often sulcate beneath for the reception of tibiae.

\section{Tibiae.}

Apical part of tibiae are very important to consider the phylogenetic relationship of the groups of Curculionoidea. Terminal surface of tibiae is frequently subdivided into corbel and tarsal groove by a longitudinal inner carina, corbel is fringed externally with a row of setae, which is called here as "outer setose fringe" and tarsal groove is fringed internally with a row of setae, which is called here as "inner setose fringe." Tibiae are often armed with mucro at the ventral angle, these tibiae are described as mucronate, and tibiae are armed of ten with uncus, which arises from the inner carina of corbel, these tibiae are described as uncinate.

In the foliage-frequenting Curculionoidea tibiae are usually subcylindrical and mucronate to increase their grasping-powers, in the barkfrequenting Curculionoidea, however, tibiae are usually flattened and uncinate to increase much stronger powers of grasping.

These structures of Curculionoidea may be divided into the following types.

\section{i. Rhynchitine-type.}

In the primitive groups such as Rhynchitinae, Anthribidae, etc., tibiac truncate vertically at tip, tarsi are inserted into the middle of the terminal surface, which is completely fringed with setae, in some Rhynchitinae there is a pair of small spurs near the ventral margin of the terminal surface.

\section{ii. Rhynchaenine-type.}

In the Rhynchaeninae, some Anthonominae, etc., terminal surface of tibiae is oblique dorso-ventrally, inner setose fringe is incomplete.

\section{iii. Notarine-type.}

Tibiae are often mucronate, terminal surface is oblique dorso-ventrally and laterally, inner carina is absent or weakly developed. In some genera such as Notaris, Procas, etc., there is a pair of small spurs near 
the base of mucro, outer setose fringe is complete, inner setose fringe is incomplete. In Brenthinae front tibiae are diverse in structure, but hind tibiae are similar to a certain unmucronate Notarine-species.

\section{iv. Amystax-type.}

Terminal surface of tibiae is subdivided into corbel and tarsal groove by a bare inner carina. It is called as "corbel semienclosed."

\section{v. Episomus-type.}

The corbel of tibiae surrounded by setae are called as "corbel enclosed." There is a fundamental difference between the enclosed and semicnclosed corbels. Terminal surface of tibiae is often double-bordered externally by the outer setose fringes, the space between these fringes is developed and forming the enclosed corbel.

\section{vi. Pissodine-type.}

In such groups as Pissodinae, Magdalinae, Styanacinae, Rhynchophoridae, ctc., the uncus is formed by a direct prolongation of the acute dorsal edge of tibiae, outer setose fringe is incomplete, forming a short dorsal border, inner setose fringe incomplcte, forming a short ventral border. Tibiae are often mucronatc. In Apoderinae the males are apparently the member of this group, the females are, however, not uncinate and belong to the groups of Notarine-type.

\section{vii. Hylobiine-type.}

In such groups as Hylobiinae, Barinae, some Cryptorrhynchinac, Bagoinae, etc., inner carina is well developed and from this carina the uncus arises, outer setose fringe is complete or nearly so, inner setose fringe is incomplete. Tibiae are often mucronate.

\section{viii. Cossonine-type.}

This group may be a slight variant of Pissodine-type, inner setose fringe is located on the lower margin of tibia, so that the tarsal groove is obsolescent.

\section{ix. Platypodid-Scolytid-type.}

In Scolytidae and Platypodidae, tibiae are strongly flattened and front tibiae are specially adapted for their lives, but hind tibiac are very important to consider the phylogenetic relationship.

In Platypodidae hind tibiae are slightly twisted from the base to the apex and strongly flattened laterally, so that the tarsal groove is narrow and oblique to the axis of tibia, terminal surface of hind tibiae is triangularly notched from lateral aspect and tarsi are inserted into the bottom of the notch. Such hind tibiae as twisted are observed in some Brenthinae, in Higonius the hind tibiae are subcylindrical, weakly twisted externally and tarsal grooves are visible from above between the dorsal and ventral protrudings. If the tibiae of such conditions are flattened, they are quite similar to those of Platypodidae. 


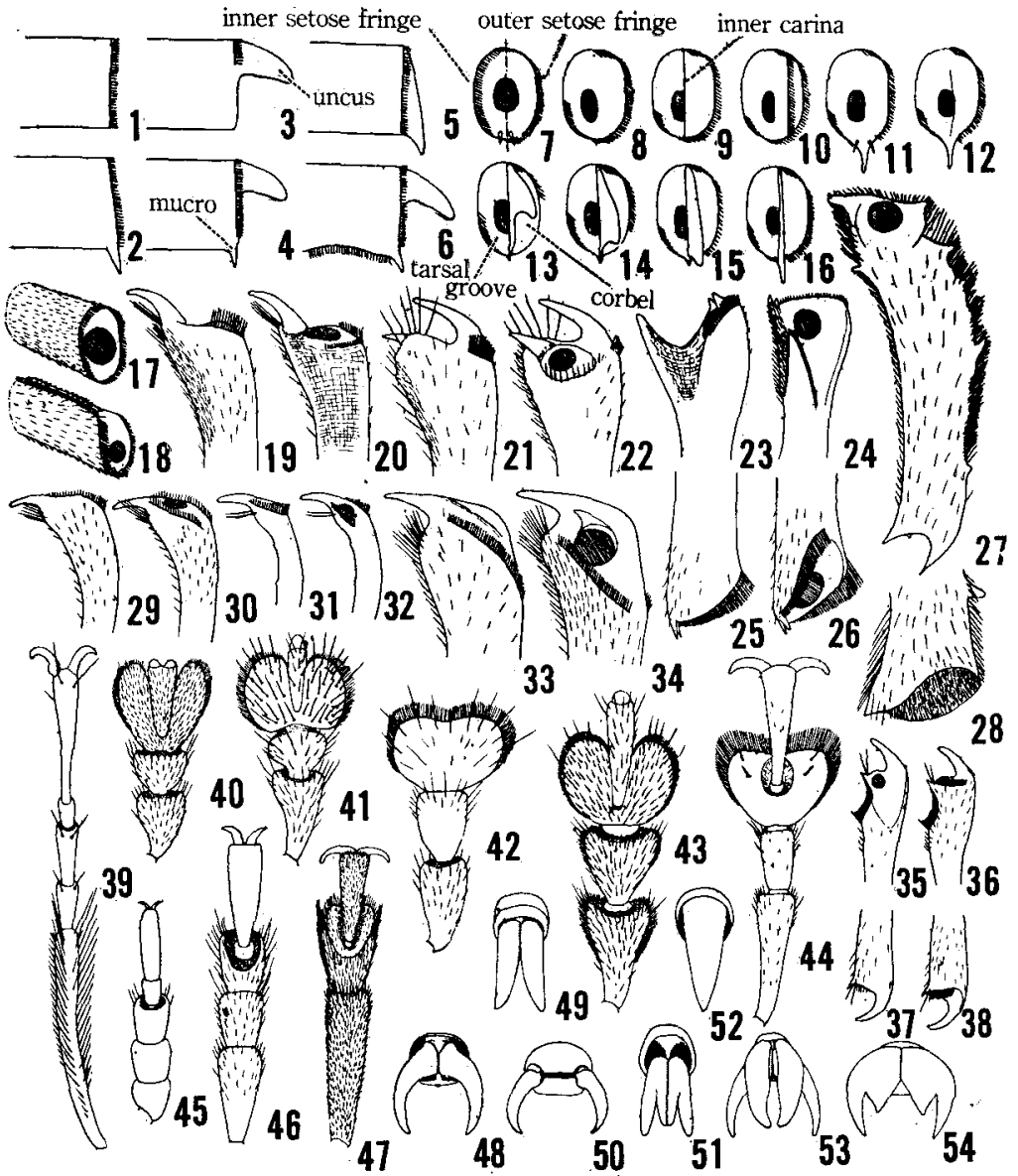

Fig. XI. Structures of legs:

1-6: Apices of tibia, lateral aspect, diagrammatical; 7-16: Terminal surface of tibia, diagrammatical; 17-38: Apices of tibia, dorsal and ventral aspects, tarsi removed; 39-47: Right front tarsi ; 48-54: Claws; 1. Tibia unarmed; 2. Tibia mucronate; 3. Tibia uncinate; 4. Tibia uncinate and mucronate; 5 . Tibia uncinate (Hylobiine-type); 6. Tibia uncinate and mucronate (Cossonine-type); 7. Inner setose fringe complete, corbel opened; 8 . Inner setose fringe incomplete, tibia unarmed, corbel opened; 9 . Terminal surface of tibia subdivided by a longitudinal inner carina, corbel semienclosed; 10 . Corbel enclosed; 11. Tibia mucronate, with a pair of spurs; 12 . Tibia mucronate; $13-16$. Tibia uncinate; 17. Anthribid-type; 18. Rhynchitine-type; 19-22. Paroplapoderus pardalis, front tibiae (19, 20. male; 21, 22. female); 23-26. Pseudorycodes insignis (23, 24, front tibiae; 25, 26. hind tibiae); 27-28. Desmidophorus crassus (27. front tibia; 28. hind tibia showing corbel); 29-30. Notaris oryzae, 
In Scolytidae the hind tibiae are presumably developed from flattened Notarine-type, in Hylesinus inner carina of corbel is absent and the outer setose fringe is highly sclerotized as a comb. From these conditions the hind tibiae developed presumably in two different ways as noted below.

\section{Hylesinus-Hylastinus-Scolytus}

In Hylastinus alni the inner carina of corbel is well developed and outer setose fringe is reduced, in Scolytus the uncus arises from the dorsal part of the inner carina and outer setose fringe is reduced, but observable.

\section{Hylesinus-Ips-Scolytoplatypus}

In the primitive groups of this series hind tibiae are truncate rectangularly at tip and the teeth of the outer fringe are less developed; in the highly differentiated groups, tibiae are, however, obliquely truncate at tip or the dorsal and terminal margins of tibiae are conjointly arched and the teeth of outer fringe are strongly developed.

It is presumable to me that the hind tibiae of the Curculionoidea are differentiated in the following way.

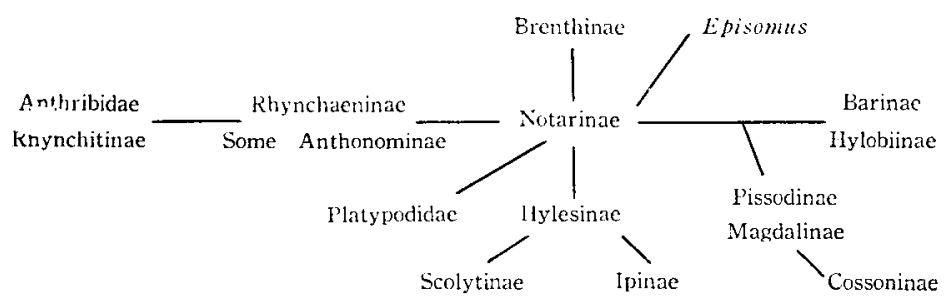

\section{Tarsi.}

Tarsus is fundamantally five-segmented, 4 th segment is small and very often invisible, in Anoplus the 4 th and 5 th segments are entirely absent. For the most part the third segment is dilated and bilobed. Underside of tarsi is very often clothed with spongy covering of dense short adhesive hairs. In such groups as Platypodidae, Dryophthorinae and Bagoinae tarsi are slender and distinctly 5-segmented, in such cases it is clothed with non-adhesive hairs or bristles, similar clothing of the tarsi are also observed in the purely terrestrial groups.

front tibiae; 31-32, Bagous bipunctatus, front tibiae; 33-34. Hylobius pinastri karafutonis, front tibiae; 35-38. Cossonus gibbirostris $(35,36$. front tibia; 37, 38. hind tibia); 39. Platypus severini; 40. Tanysphyrus lemnae; 41. Galloisiia inflata; 42. Anoplus sugiharai; 43. Catapionus viridimetallicus; 44. Otidognathus jansoni; 45. Dryophthorus sculpturatus; 46. Cossonus gibbirostris; 47. Tropideres germanus ; 48. Syrotelus septentrionalis; 49. Lixus acutipennis ; 50. Hyposipalus gigas; 51. Mesalcidodes trifidus; 52 . Stereonychus ogasawarai; 53 . Aderorhinus crioceroides; 54 . Apion placidum. 


\section{Claws.}

The structure of claws is of much systematic value in the lower categories. They are fundamentally capable of independent movement, but are always closely approximated at the base, these claws are simply described as "free", in many groups claws are fused together at the base, being called as "connate", in a few cases there is only a single claw, occasionally claws are armed with a tooth and more rarely they are cleft.

\section{ELYTRA}

Elytra are always strongly sclerotized and covering the whole or major part of the abdomen. Typically each elytron bears ten punctured striae, the 10th stria is often visible only on the basal half. In some Anthribidae and Attelabidae elytron bears a shoit scutellar stria between the 1st stria and suture.

The fundamental disposition of tracheae of elytra is observed in Phialodes. The six tracheae arise in two groups, a cost-median group and cubito-anal one. These tracheae were interpreted by Crowson (1955) as $\mathrm{C}+\mathrm{Sc}, \mathrm{R}, \mathrm{M}, \mathrm{Cu}, 1 \mathrm{~A}$ and $2 \mathrm{~A}$ from the anterior to the posterior respectively, another interpretation was given by Jeannel (1925) as $\mathrm{R}, 1 \mathrm{M}$, $2 \mathrm{M}, 1 \mathrm{Cu}, 2 \mathrm{Cu}$ and $\mathrm{A}$. In this paper terms are followed after Crowson.

Relative position of tracheae, striae and lateral fold of elytra are very important in considering the relationship of the major groups of the Curculionoidea.

In Attelabidae elytral epipleuron lies on the outer surface and freely visible from the side, but in the remaining families occurring in Japan the epipleuron is located on the inner surface of elytra.

Cost-subcostal trachea (if present) is located between the 10th stria and the lateral margin of elytra in Anthribidae and Attelabidae, but this trachea is located between the 9 th and 10th striae in the remaining families.

From these characters of elytra the Curculionoidea may be divided into three groups and the relationship of these groups may be as follows:

Attelabidae-Anthribidae-The other families

Disposition of tracheae and striae will be expressed in the following way:

Mesalcidodes: 1.C +Sc. 1. R. 4. Cu.2.1A.2A.O

The figures noted between the abbreviated terms of tracheae reveal the number of striae between the named tracheae. Last figure reveals the presence or absence of the scutellar stria. Fundamental disposition may be represented by the following two types:

Attelabid-Anthribid-type: 0.C+Sc. 2. R.2. M.2. Cu. 2.1A.2.2A. 1 or O 
Curculionid-type $\quad$ : 1.C +Sc.1.R.2. M.2.Cu.2.1A.2.2A. O

Radius and 1st analus are always present. Cost-subcosta is very of ten vestigial or absent. Media is frequently absent. The other tracheae are also often absent in the following ways:

Phyllobius, Eugnathus, Curculio, Cossonus, Xyleborus, Nanophyes, etc.

1 or O. C+Sc.1.R.2.M.2.Cu.2.1A.2.2A. O Fundamental type.

Mesalcidodés, Lixus, Hyposipalus, Ceuîhorrhynchus, Sitonâ, Rhinoñuis, Scolytoplatypus, etc.

1 or O.C+Sc.1.R.4.Cu.2.1A.2.2A.O M absent.

Scepticus, Myllocerus, etc.

1.C+Sc.1.R.4.Cu.2.1A.2.O

$\mathrm{M}$ and $2 \mathrm{~A}$ absent.

Apion

2.R.4.Cu.2.1A.2.O

$\mathrm{C}+\mathrm{Sc}, \mathrm{M}$ and $2 \mathrm{~A}$ absent.
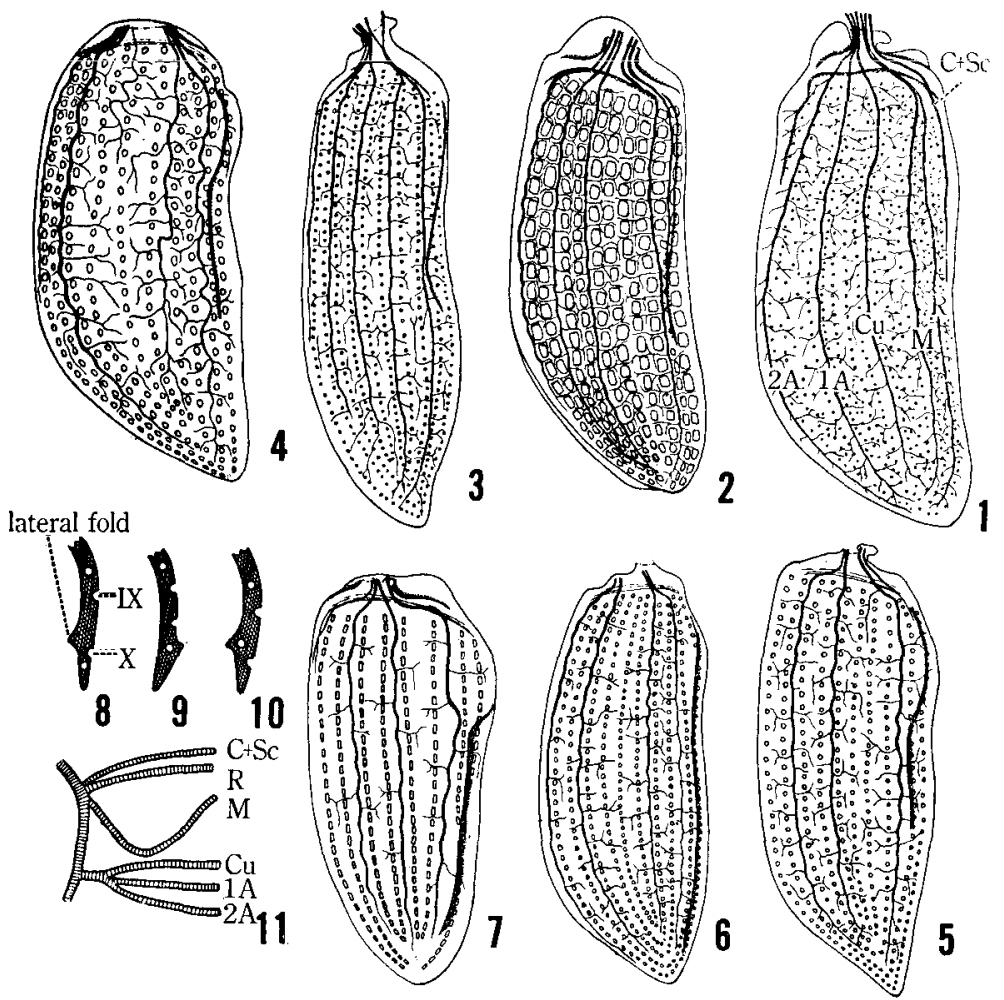

Fig. XII. Structures of elytra.

1-7. Ventral aspects; 8-10. Cross-section of the lateral margin of elytron, diagrammatical; 1. Phialodes rufipennis; 2. Mesalcidodes trifidus; 3 . Phyllobius rotundicollis; 4. Dermatoxenus caesicollis; 5 . Scepticus sp.; 6. Apion sp.; 7. Centrinopsis nitens; 8. Anthribid-type; 9. Attelabid-type; 10. Curculionid-type; 11. Phialodes rufipennis, basal part of the tracheae of elytron. 
Centrinopsis 2.R.2.Cu.2.1A.2.2A.O

Elytron with 8 striae.

Apoderus, Phymatapoderus, Cycnotrachelus, Paracycnotrachelus, etc.

O.C+Sc.2.R.4.Cu.2.1A.2.O $\mathrm{M}$ and $2 \mathrm{~A}$ absent.

Phialodes, Euops, etc.

O.C+Sc.2.R.2.M.Cu.2.1A.2.2A.O Fundamental type.

Byctiscus, Deporaus, etc.

O.C + Sc. 1 or 2.R.2.M.2.Cu.2.1A.O $2 \mathrm{~A}$ absent.

Intervals containing tracheae are often broader than the others, often costate or tuberculate.

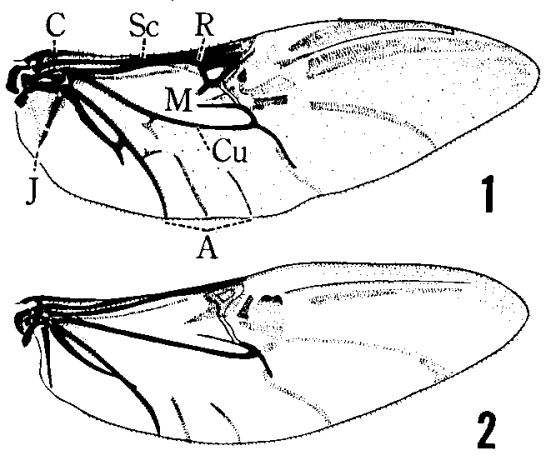

Fig. XIII. Wings of :

1. Phialodes rufipennis;

2. Phyllobius rotundicollis.

\section{WINGS}

Anal vein of the hind wing of the Curculionoidea may fundamentally divided into 5 branches as in Belus (Crowson, 1955). We can observe 4 branches in Attelabidae and 1-3 branches in the other families inhaviting in Japan.

Reduction of the hind wing is often correlated with the terrestrial habit and such species have the elytra with humeri rounded or vestigial.

ABDOMEN

\section{General morphology.}

In the ventral aspect only five segments are normally visible, the two basal ones having deeply inflected inwards and forming the posterior wall of coxal cavities.

Fundamentally abdomen is composed of 9 segments in number in both sexes, 8th and 9 th segments are of ten telescoped into the 7 th, 8 th segment is less sclerotized and smaller than the 7 th, 9 th tergite is always absent in male and 9th segment is always absent in female excepting Anthribidae, in which is found the 9th tergite in both sexes, 9th sternite is absent in the male of Platypodidae.

As already be reported by Leconte and Horn (1876), 8th tergite is very often withdrawn entirely into the 7 th segment and 7 th tergite forming pygidium in the female, posterior margin of the 8 th sternite is rarely visible from above. In the male the 7th tergite forms the pygidium in Anthribidae, Attelabidae, Platypodidae, Scolytidae and Rhynchophoridae, 8th tergite is visibly terminal and forming the pygidium 
in Brenthidae and Curculionidae as a rule.

Pygidium is often longitudinally sulcate on the basal half in Anthribidae, Ithycerinae and some Rhynchophoridae and into this sulcus the ventral flanges of the suture fit tightly when disturbed.

\section{Tergal region.}

Tergites are less strongly sclerotized than the sternites and freely
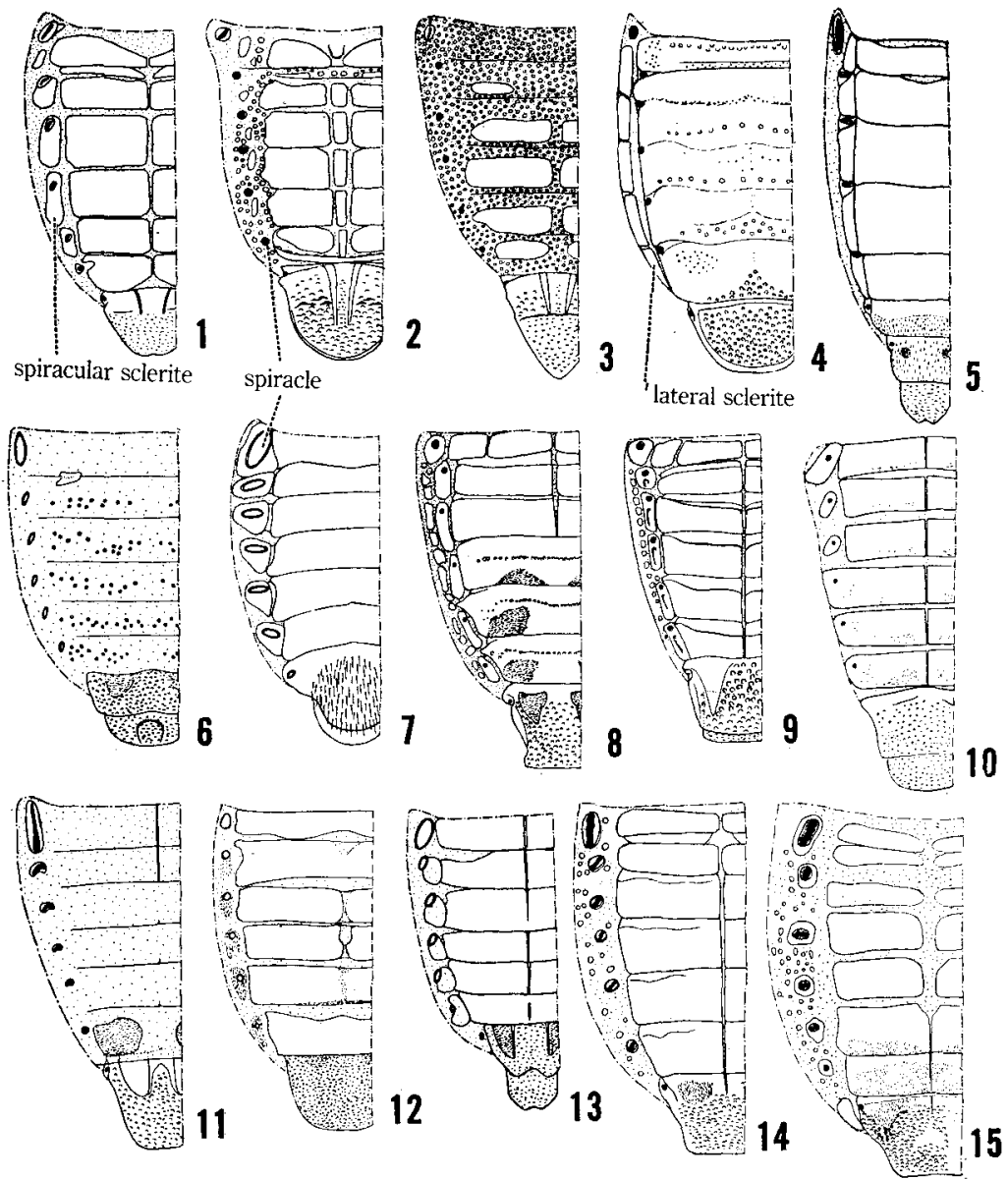

Fig. XIV. Tergal region of abdomen of :

1. Tropideres laxus, 우; 2. Autotropis distinguendus, 우; 3. Araecerus tibialis, 우; 4. Cycnotrachelus nitens, 우; 5 . Baryrrhynchus poweri, 오; 6. Desmidophorus crassus, ठ7; 7. Platypus modestus, ว ; 8. Didothis melancholica, 우 ; 9 . Centrinopsis nitens, 0 ; 10. Orobitis apicalis, ${ }^{3}$; 11. Hyposipalus gigas, $\overrightarrow{0} ; 12$. Notaris okunii, 우; 13. Ectatorhinus adamsi, 3; 14. Mesalcidodes trifidus, 우; 15. Mecyslobus erro, 오. 
articulated to each other excepting Attelabinae, of which the 1st-6th tergites are entirely conglutinate.

Tergite may be divided into three regions, a large median sclerite, spiracular sclerites and lateral sclerites. Tergal region of the abdomen may be divided into the following four types:--

i. Attelabine-type.

Lateral sclerites are well developed. Spiracular and median sclerites are entirely conglutinate. Often the 1st spiracular sclerite is separated from the median one. This type is found in such groups as Attelabinac, Byctiscini, Rhynchitini, Deporaina, and Barinae.

\section{ii. Platypodid-type.}

Lateral sclerites are entirely absent. Spiracular sclerites are well distinguishable from the median one, the 7 th spiracular sclerites are always fused with the median one. Spiracular sclerites are of ten subdivided into small pieces. This type is found in such groups as Anthribidae, Brenthinae, Mecyslobinae and Ectatorrhinus.

\section{iii. Ceuthorrhynchine-type.}

It may be an intermediate type of Attelabine- and Platypodine-ones. Spiracular sclerites are separated from the median one in the 1st-3rd tergites and connate with the median one in the remaining tergites. Lateral sclerites are always absent. Median sclerites of the 1st-6th tergites are very often subdivided by a narrow median membraneous streak. This type is found only in Ceuthorrhynchinae.

iv. Common-type.

In the remaining groups the lateral and spiracular sclerites are absent. Median sclerites are often less sclerotized or membraneous or of ten subdivided at the middle.

\section{Sternal region.}

Sternum of abdomen consists of 8 sternites in the female and 9 ones in the male excepting Platypodidae, of which the 9th sternite is absent. Two basal sternites are deeply inflected inwards and forming the posterior wall of metacoxal cavities. Third sternite is the visible 1 st segment of abdomen, 7 th sternite is visibly terminal, 8 th sternite is telescoped into 7th segment in both sexes excepting Cycnotrachelus (Apoderini), of which the 8 th sternite is absent in the female, 9 th sternite is absent in the female and small in the male.

Third-7th sternites are freely movable in Anthribidae and Platypodidae, 3rd and 4th sternites are more or less soldered together in Brenthidae, Scolytidae, Curculionidae and Rhynchophoridae. In Attelabinae the 3 rd-6th sternites are connate. In Rhynchitinae it has a tendency to connate the 3rd and 4th sternite in Rhynchitini and Deporaini, 3rd5 th sternites are more or less soldered in $\Lambda$ uletini, and in Byctiscini the 3rd-6th sternites having a tendency to connate at the sides. The 
suture between the 6th and 7th sternites is deeply inflected inwards in Anthribid-Platypodid-type.

In the female 8th sternite, the so-called genital segment, bears an aphophysis in major groups, aphophysis is absent in most Attelabinae and Arrhaphogaster (Celeuthetini). Length of the aphophysis may probably be correlated with the length of ovipositor.

The 8th sternite is a little smaller than and having similar shape to the 8th tergite in Anthribidae, Attelabidae and Platypodidae, in the other families the 8th sternite is generally much smaller than the 8th tergite and the lateral areas are membraneous.

In the male 9th sternite, the so-called genital segment is small excepting Rhynchophoridae, of which the 9th sternite is short troughshaped. Aphophysis is attached to the middle of the inner margin of the 9 th sternite in major groups, aphophysis is often prolonged anteriorly towards the dorsal surface of penis through the right side of penis. Aphophysis is lacking in Otidognathus (Rhynchophorini).

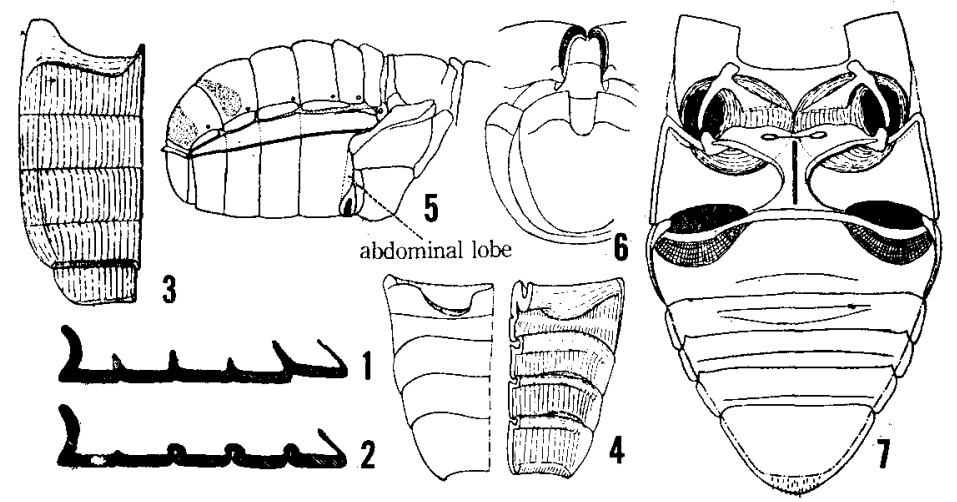

Fig. XV. 1-2: Longitudinal cross-section of abdominal sternite, showing two types of the articulation; 3. Autotropis distinguendus, inside of the abdominal sternite, left half ; 4. Orobitis apicalis, abdominal sternite, right half, dorsal and ventral aspects; 5 . Abdomen of Byctiscus princeps, lateral aspect, showing the costa along the margin of elytron in repose; 6. Caudal aspect of Tropideres germanus, showing the relation between the sulcus on pygidium and sutural flange of elytra; 7. Blosyrus japonicus, sternal region of meso- and metathorax and abdomen, dorsal aspect, showing the characteristic metendosternite.

MALE gENITAL ORGAN

\section{Accessory gland.}

Accessory gland is three to eight paired in Attelabidae, one or two paired in the majority of the Curculionoidea and always one-paired in Rhynchophoridae. 


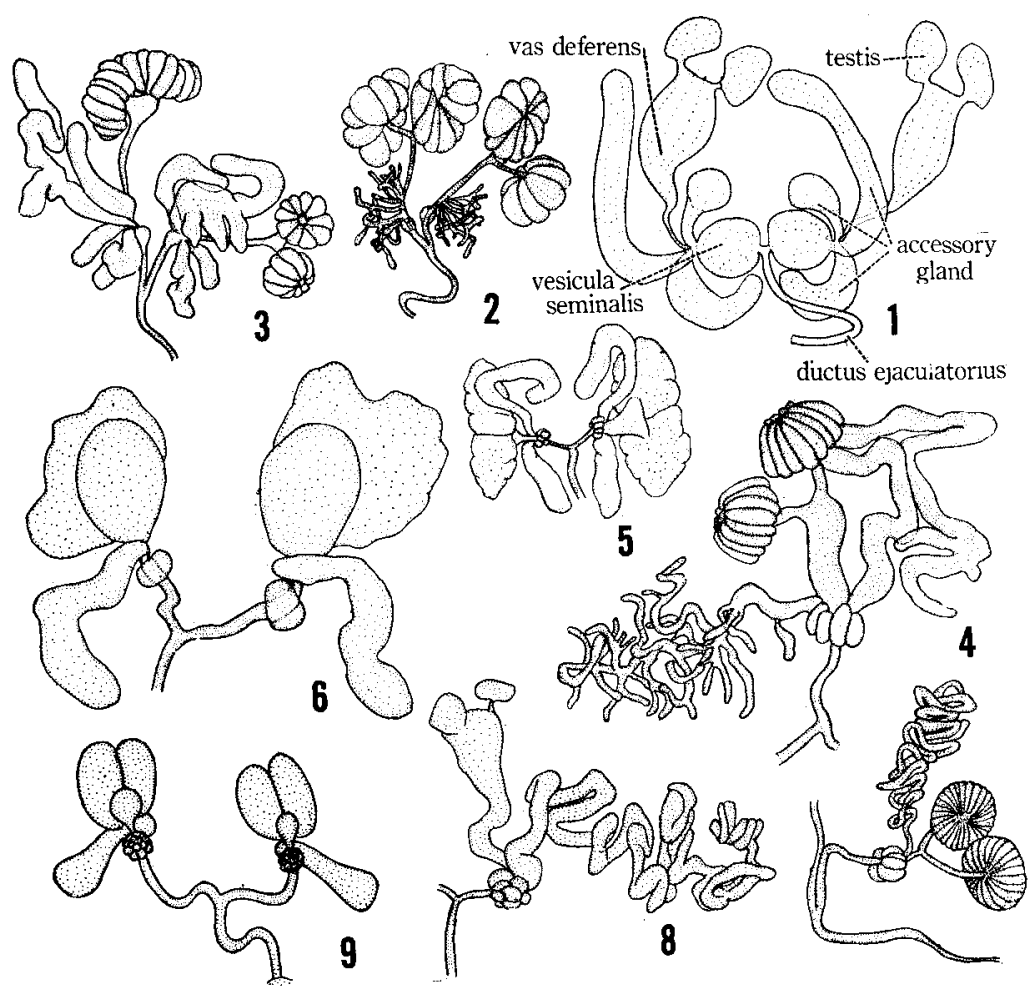

Fig. XVI. Internal genital organs of male of:

1. Auletobius uniformis; 2. Phialodes rufipennis; 3. Apoderus erythrogaster;

4. Lixus impressiventris; 5 . Rhinoncus jakovlevi; 6. Diocalandra elongata;

7. Hyposipalus gigas; 8. Otidognathus jansoni ; 9. Cylas formicarius.

\section{External organ.}

External male genital organ of the Curculionoidea consists of aedeagus and 9th abdominal sternite, the latter was already treated in the chapter of abdomen.

From the phylogenetic point of view the important morphological characters of aedeagus are the structures of penis and cap-picces of tegmen.

The structure of penis varies from paired-type to a simple troughtype. In the families Anthribidae and Attelabidae the apical major part of penis is divided into dorsal and ventral plates, these plates are nearly equal in size, ostium is located between the apical margins of the plates. In the families Brenthidae and Curculionid genus Notaris the dorsal plate is much narrowed and a little shortened and ventral plate is more or less trough-shaped, ostium is located dorsally between the apical margins of the plates. In the species of the Rhynchophoridae 
dissected, the dorsal plate is similar to that of Brenthidae, or the plate is simply bridged between the basal part of the lateral margins of the ventral plate. Transitional types combine these two types. Ventral plate is deep trough-shaped. with a distinct lateral membraneous incision, and this incision is short in Tetratemnus, or extending near the apex in Hyposipalus, Otidognathus, etc., or curved before the middle in Dryophthoroides. In Platypodidae dissected the dorsal plate of penis is reduced to a sclerotized bridge along the dorsal margin of the basal edge.

In the families Scolytidae and Curculionidae (excluding Notaris) the dorsal plate is entirely lacking, the ventral plate is deep trough-shaped, dorsal part of penis is membraneous, or weakly sclerotized or often the ventral plate entirely enfolds the internal sac, ostium is located always on the dorsal surface near the apex of penis.

Median struts that is extending anteriorly are paired rods attached to or articulated with penis. These struts are nearly as long as or often much longer than penis in most species of the Curculionoidea dissected, while in Cleoninae the struts are short and in Platypodidae vestigial. Their mode of attachment and shape are variable.

Internal sac varies in size, shape and length. The inner wall of the internal sac is often armed with sclerites and spines in various ways. A sclerite attached to the gonopore of internal sac is called flagellum, which becomes external when everted the sac. Flagellum, spines and the other sclerites are very important to recognize the species as a stable character, but these do not serve as good characters in the consideration of phylogeny.

Tegmen is typically divided into the basal piece, cap-piece and tegminal strut.

In the families Anthribidae and Attelabidae the cap-picce of tegmen is triangular or subtrapezoidal and the anterior margin is clothed with setae. In the subfamilies Brenthinae and Apioninae tegmen formes a ring bearing a pair of large and rounded lobes, which are forming one piece basally, the lobes being hirsute near the apex. The cap-piece is nearly flat and notched in the subfamilies Nanophyinae, Cyladinae, Desmidophorinae and Curculionid genus Notaris. Cap.piece is articulated to the basal piece in the species of Notaris and Brenthinae. In the families Curculionidac (excluding Notaris), Rhynchophoridae and Scolytidae tegmen is ringed or opened dorsally, cap piece is much smaller than that in the above mentioned groups, often paired or of ten entirely absent. In the family Platypodidae tegment is always Y-shaped. Tegminal strut varies in length and shape in various ways, often vestigial.

Some considerations on the previous works on the external male genitalia of the Curculionoidea.

External male genitalia of the Curculionoidea was studied fragmentarily by Lindeman (1875, Scolytidae), Verhoeff (1896, Scolytidae), 

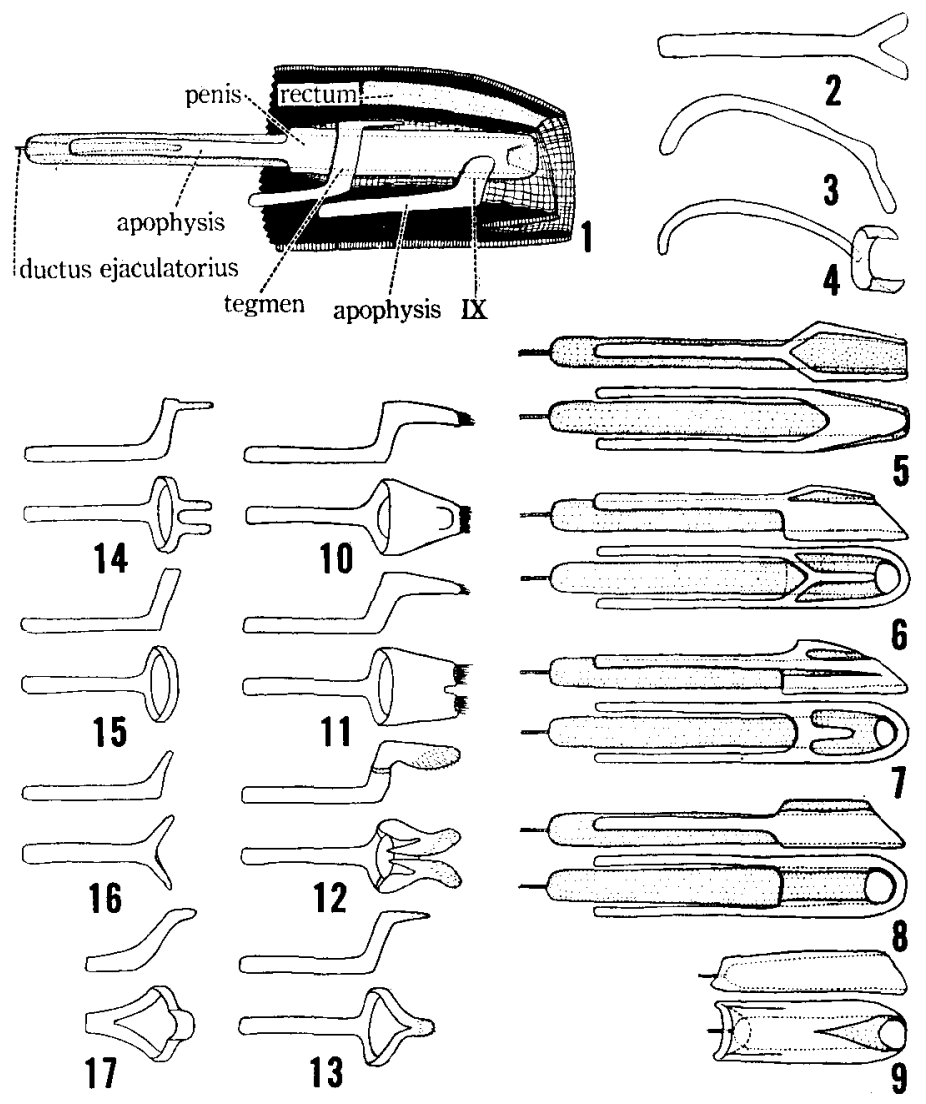

Fig. XVII. Diagrams of the external genital organs of male.

1. External genital organs, lateral aspect; $2-4.9$ th sternite; 5-9. Penis, lateral and dorsal aspects; 5. Anthribid-Attelabid-type; 6. Brenthid-Notaris-type; 7. Rhynchophorid-type; 8. CurculionidScolytid-type; 9. Platypodid-type; 10-17. Cap-piece, basal piece and aphophysis of tegmen, lateral and dorsal aspects; 10. AnthribidAttelabid-type; 11. Cylas-Nanophyes-type; 12. Brenthine-ApionineDesmidophorine-type; 13-17. Curculionid-Scolytid-Platypodid-type.

Nüsslin (1912, Scolytidae), Hopkins (1915, Scolytidae, Platypodidae), Strohmeyer (1920, Platypodidae), Sharp and Muir (1912, 1918), Bruhn (1947) and many other taxonomists.

Phylogenetic studies of the Curculionoidea was first attempted by Sharp and Muir (1912), but this work was based on scanty materials and fallen into a certain dogma of the theory. Bruhn (1947) studied extensively and an excellent interpretation was given to the male genitalia from the phylogenetic point of view, but it seems to me that Bruhn failed to notice the dorsal plate of penis in several species, that 


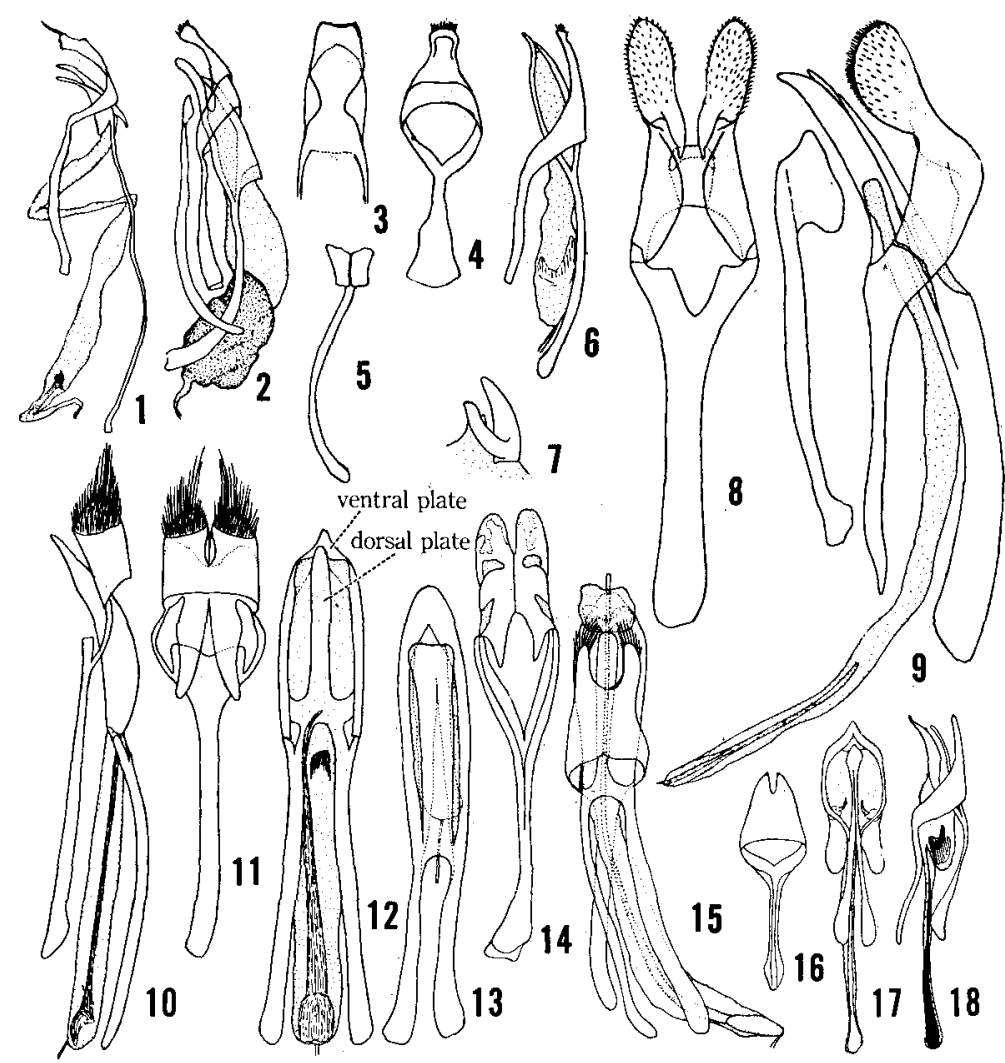

Fig. XVIII. Exterial male genital organs of :

1. Araecerus fasciculatus, lateral aspect; 2-5. Henicolabus lewisii (3. penis, ventral aspect; 4. tegmen; 5. 9 th sternite); 6-7. Deporaus unicolor (7. sclerite on the inside of inner sac); 8-9. Baryrrhynchus poweri (8. tegmen); 10-12. Desmidophorus crassus; 13-14. Apion sp.; 15. Ithycerus noveboracensis; 16-18. Cylas formicarius.

is, in Anthribidae dissected the dorsal plate is well developed as in the ventral plate, and in Apion the dorsal plate is narrow, but distinct. He stated on the penis of the Rhynchophoridae as "The median lobe (= penis) usually consists of a dorsal and ventral plates which are separated laterally by a narrow strip of membrane", but on the dorsal part of penis of the Rhynchophoridae there is a developed or less developed dorsal plate (cf. Hyposipalus, Otidognathus) and the lateral wall of the ventral plate is incised from the anterior edge towards the apex.

Following is a summary of the comparative morphology of the aedeagus of the Curculionoidea dissected.

1. Families Anthribidae and Attelabidae are close to each other, 


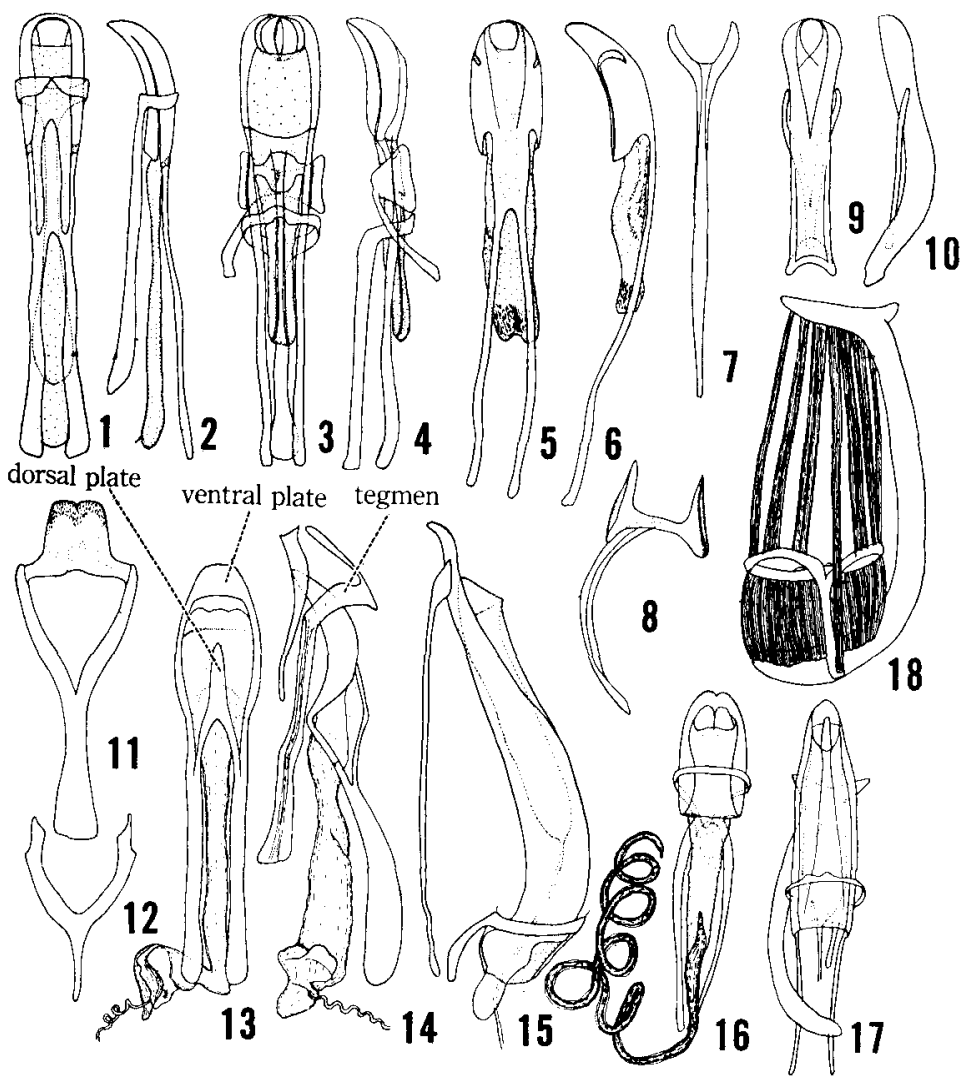

Fig. XIX. External male genital organs of:

1-2. Hyposipalus gigas; 3-4. Cryptoderma fortunei; 5-8. Dryophthoroides sulcatus (7. 9th sternite; 8. tegmen); 9-10. Platypus modestus; 11-14. Notaris funebris (12. 9 th sternite); 15. Lixus impressiventris; 16. Tanysphyrus lemnae; 17-18. Rhinoncus jakovlevi (18. musculature between 9 th sternite and tegmen).

having such characters as: posterior major part of penis divided into dorsal and ventral plates, which are equal in size; ostium located on the terminus of penis; cap-piece of tegmen not bilobed, triangular or trapezoidal, large, anterior margin clothed with setae.

2. Subfamilies Brenthinae and Apioninae are very close to each other. Cyladinae, Nanophyinae, Ithycerinae, Desmidophorinae and the genus Notaris are fairly close to the Brenthine-Apionine group. Above mentioned groups are characteristic by the following structures: posterior major part of penis divided into dorsal and ventral plate, ventral plate more or less trough-shaped; ostium located on the dorsal surface near the apex; cap-piece of tegmen large, bilobed, often articulated to 
the basal piece, apical part of cap-piece hirsute or setaceous.

3. Family Rhynchophoridae is distinctive in the following characters: dorsal plate of penis less developed, ventral plate is incised laterally; cap-piece of tegment less developed, vestigial or absent.

4. Family Platypodidae is very distinctive from the other families in the following characters: median struts of penis vestigial; tegmen always Y-shaped, dorsal plate of penis reduced to a bridge along the basal margin.

5. Families Curculionidae (excluding Notaris) and Scolytidae are very close to each other having the following characters: dorsal plate of penis lacking, ventral plate well developed, deep trough-shaped or often tubular; cap-piece of tegmen less developed, vestigial or absent.

6. The relationship of these groups may be illustrated as follows.

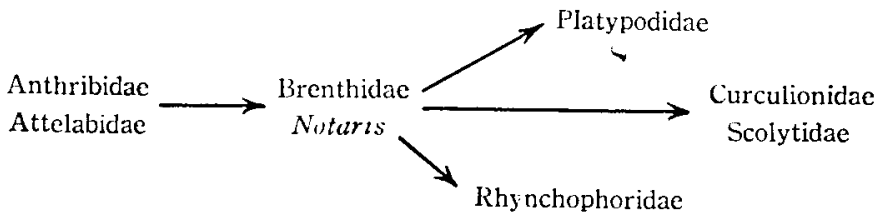

FEMALE GENITAL ORGAN

\section{Ovariole.}

Ovarioles are 4-5 paired in Anthribidae and Attelabidae, two-paired in the other families.

\section{Ovipositor.}

Ovipositor consists of coxite and stylus, coxite is often subdivided and stylus is often absent.

Ovipositor of Curculionoidea will be divided into the following three types.

i. In Attelabinae, Platypodidae and Scolytidae the ovipositor is vestigial, stylus is always absent, coxite is very often absent. In any case the gonopore is not embraced by coxites.

ii. In Anthribidae the stylus is strongly sclerotized and toothed, coxite is deeply inflected inwards from above, so that it may be presumable that the toothed styli move laterally to pore the ovipositing hole.

iii. In the other families, the coxite and stylus are fundamentally well developed, stylus is of ten absent, coxite is often subdivided. Length of the coxite may be correlated with the length of female rostrum.

In the Curculionidae Adelognathi the ovipositor is diverse in structure as follows and their relationship may be presumable as in the text- 


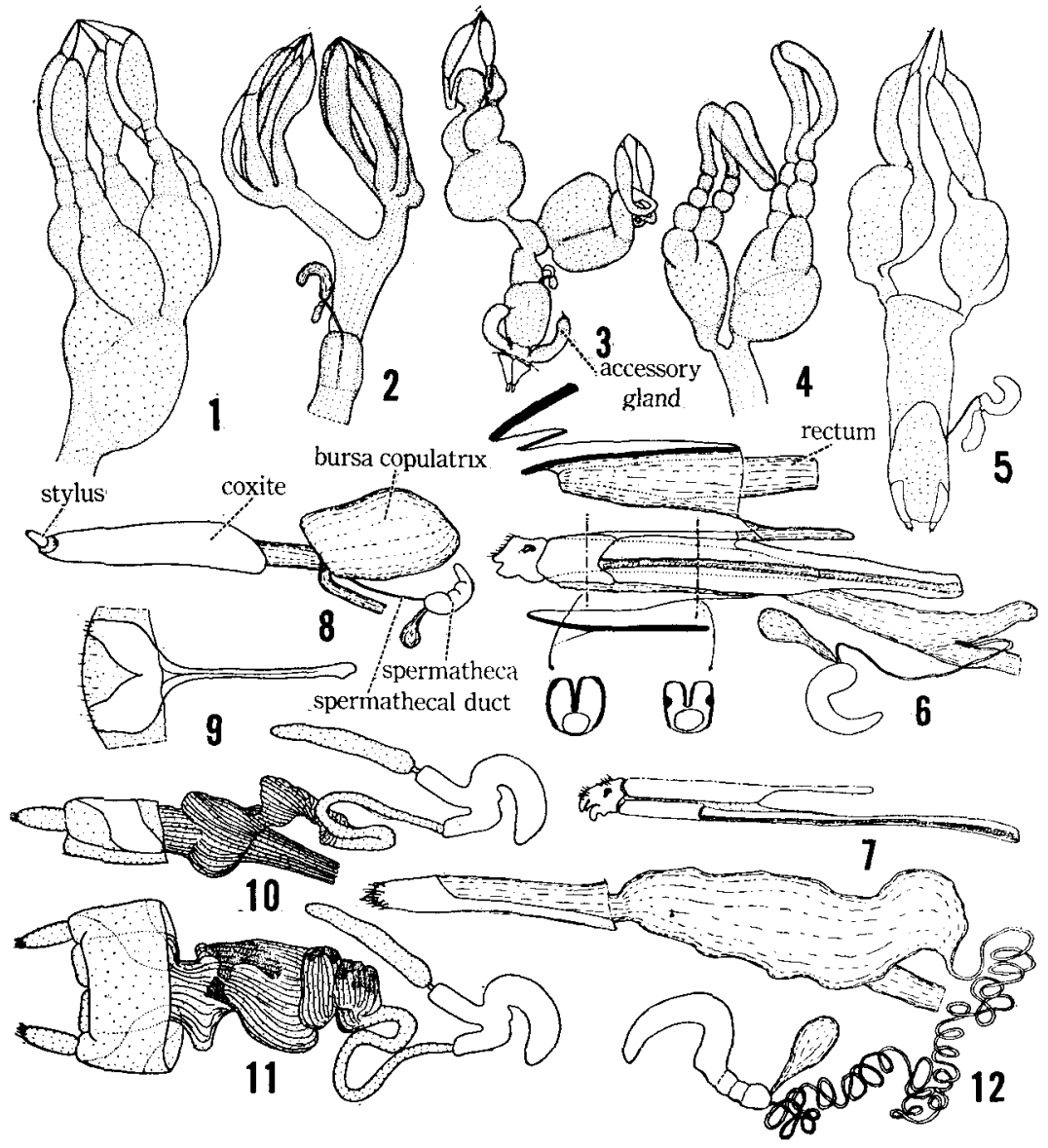

Fig. XX. Female genital organs of:

1-5: Ovary; 6-12: Ovipositor and sperpatheca; 1 . Byctiscus venustus, left half; 2. Phialodes rufipennis; 3. Larinus ovalis; 4. Metialma pusilla; 5. Mecyslobus erro; 6-7. Tropideres laxus (7. ovipositor, left half, dorsal aspect); 8. Apion sp.; 9-11. Desmidophorus crassus (9. 8 th sternite); 12. Baryrrhynchus poweri.

figure XXII.

a. Coxite simple, stylus present.........................some Otiorrhynchus

b. Coxite simple, very short, stylus absent................. Sitona, Eugnathus

c. Coxite with a dorsal incision, stylus present.......some Otiorrhynchus, Asphalmus, Callirhopalus, Catapionus, Dermatoxenus, Episomus, Byrsopages

d. Coxite with a dorsal incision, stylus absent...Chlorophanus, Sympiezomias, Scepticus 
e. Coxite with a dorsal incision, dorsal area before the incision not sclerotized, stylus present..... Amystax

f. Coxite subdivided into two parts, stylus present......Blosyrus, some Scythropus

g. Coxite subdivided into two parts, basal piece not sclerotized excepting baculus........................Pachyrrhynchus, Trachyphloeosoma

h. Coxite with the basal part membraneous, stylus present......some Scythropus

i. Coxite with the basal membrancous part developed and wrinkled, stylus absent. .Phyllobius, Myllocerus, Myosides, Hyperstylus,
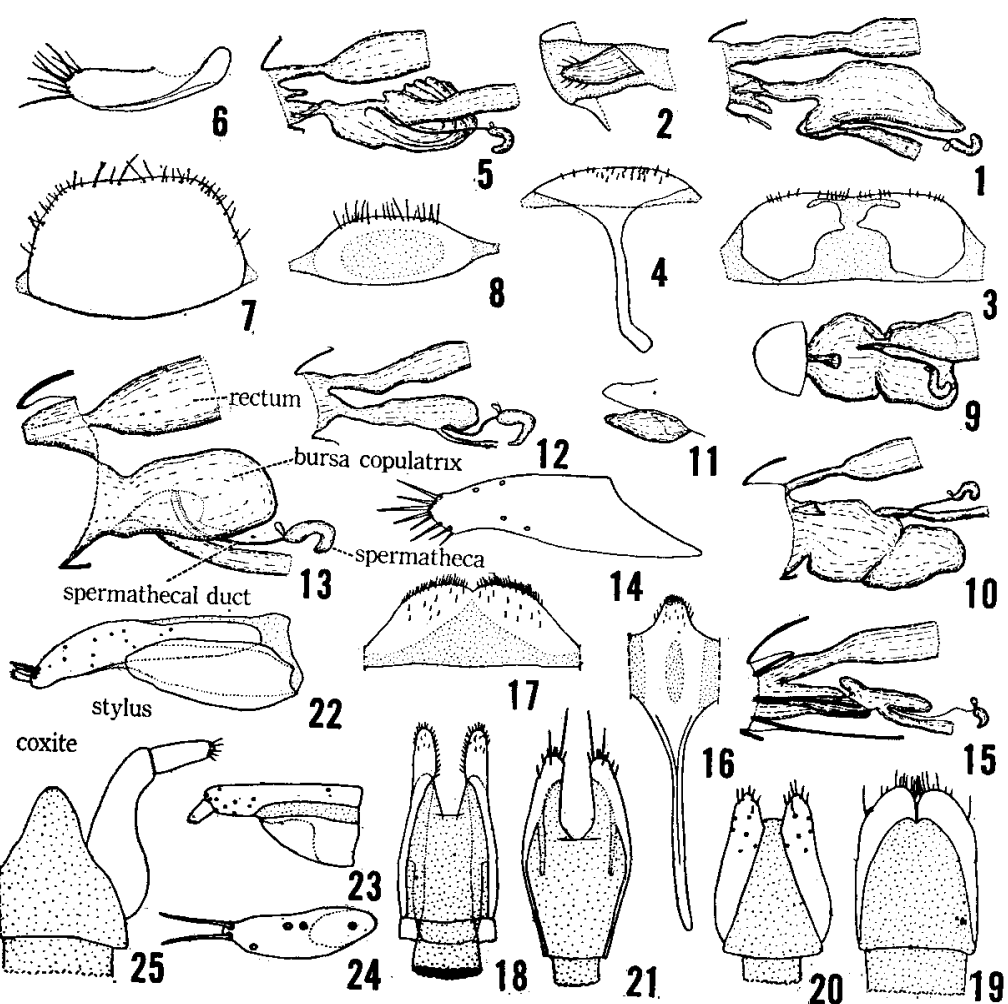

Fig. XXI. Ovipositors of Attelabidae.

1-4. Phialodes rufipennis (2. coxite; 3 . 8th tergite; 4. 8th sternite); 5-8. Henicolabus lewisii (6. coxite, enlarged; 7. 8th tergite; 8. 8th sternite); 9-11. Paratrachelophorus longicornis (11. coxite, enlarged) ; 12. Euops splendida; 13. Paracentrocorynus nigricollis; 14 . Lasiorhynchites brevirostris, right coxite; 15-18. Rhynchites heros (16. 8th sternite; 17. 8th tergite); 19. Mecorhis ursulus; 20. Auletobius uniformis; 21. Byctiscus venustus; 22. Chokkirius truncatus; 23. Deporaus unicolor; 24. Chonostropheus chujoi; 25. Eugnamptus flavipes. 


\section{Canoixus, Cyphicerus, Oedophyrus, Cyrtepistomus}

j. Coxite with the terminal part subdivided into two sclerites, basal part developed as in above, stylus present..............Trachyrhinus, Arrhapogaster

\section{Bursa copulatrix.}

Bursa copulatrix is a pouch of the genital chamber. In the majority of the Curculionoidea bursa copulatrix is located above the oviduct,

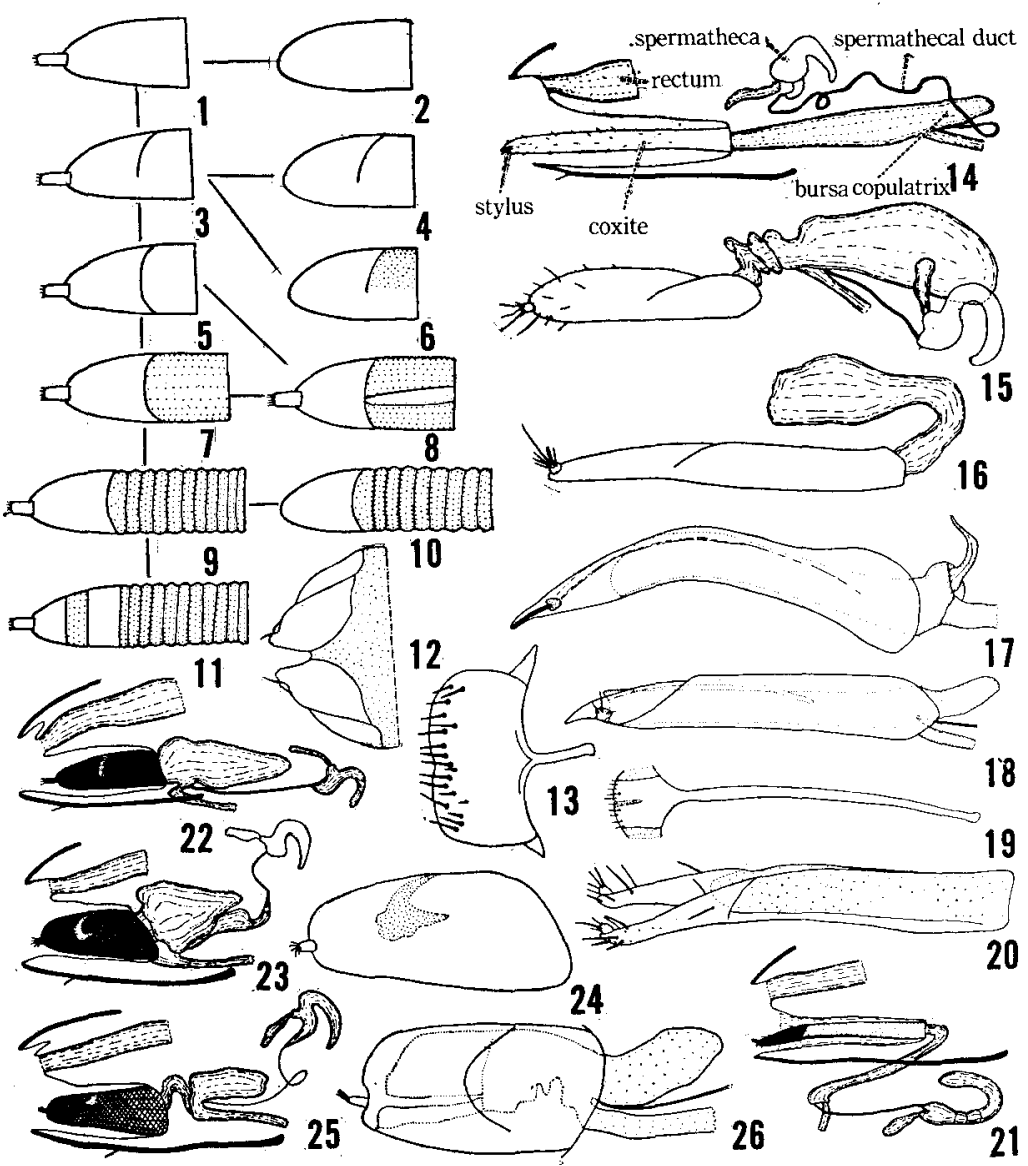

Fig. XXII. Ovipositors of Curculionidae adelognathi.

1-11: Scheme of the progressive differentiation; 12-13. Eugnathus distinctus (12. ventral aspect of coxite; 13. 8th sternite); 14. Otiorrhynchus avalis; 15. Otiorrhynchus sulcatus; 16. Asphalmus japonicus; 17. Chlorophanus grandis; 18. Scepticus sp.; 19-21. Amystax fasciatus (19. 8th sternite; 20. ovipositor, enlarged); 22. Callirhopalus bifasciatus; 23-24. Catapionus viridimetallicus (24. ovipositor, enlarged); 25. Dermatoxenus caesicollis; 26. Episomus turritus. 
while in Attelabinae its position is not lixed generally. In Euops, Phialodes and Paracentrocorynus it is dorsal, in Henicolabus and Cycnotrachelus lateral and in Apoderus and Paratrachelophorus ventral to the oviduct in position.

Spermathecal duct opens usually at the bursa copulatrix close to the gonopore, but in such genera as Desmidophorus, Cylas, Baryrrhynchus, Dorytomus, Lobotrachelus, Mecopomorphus, etc., it opens at the apex of the bursa copulatrix.

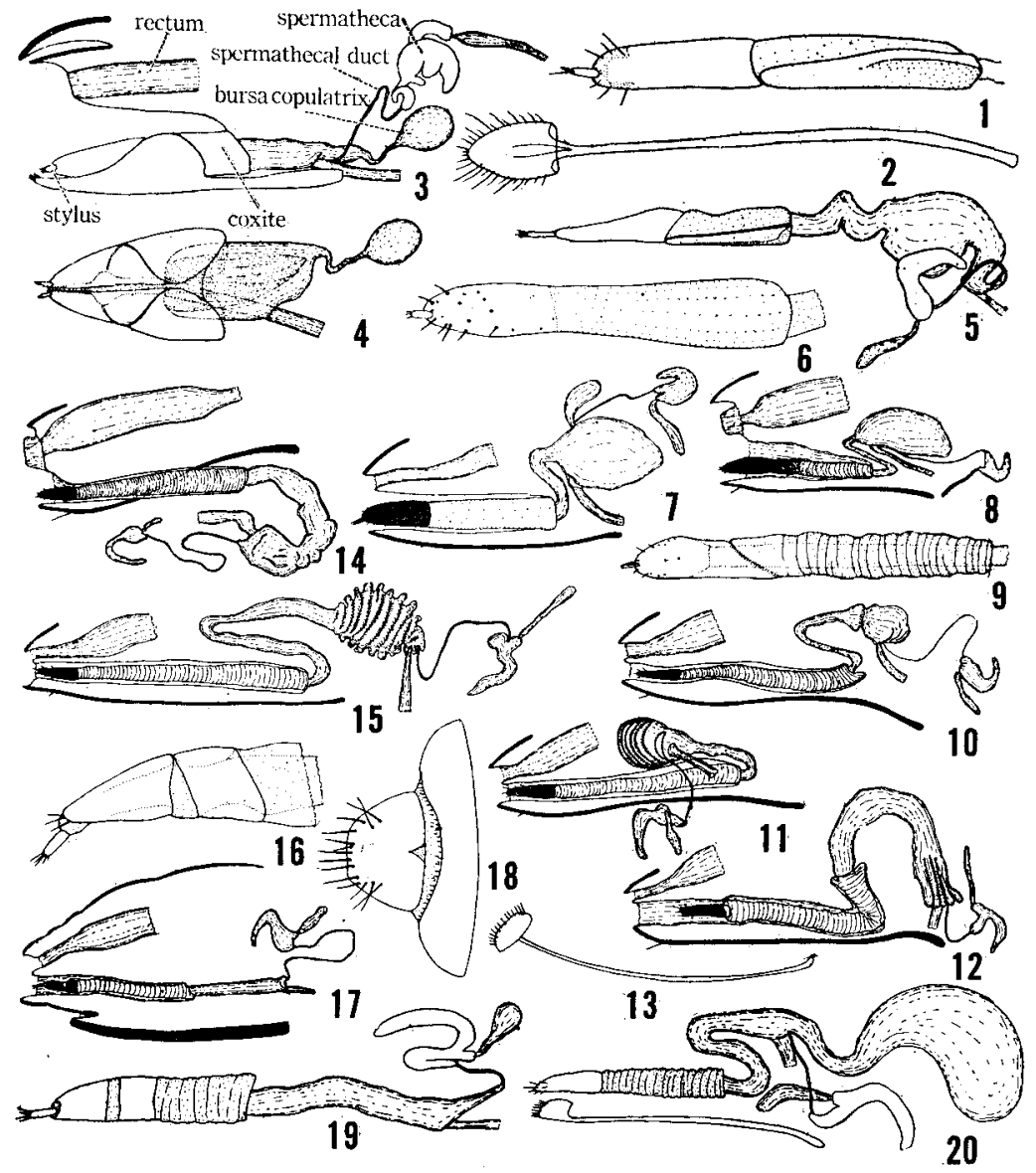

Fig. XXIII. Ovipositors of Curculionidae adelognathi.

1-2. Pachyrrhynchus infernalis (2. 8th sternite); 3-4. Blosyrus japonicus;

5. Trachyphloeosoma sp.; 6-7. Scythropus ornatus (6. ovipositor, enlarged); 8-9. Phyllobius rotundicollis (9. ovipositor, enlarged); 10. Anosimus decoratus; 11. Calomycterus setarius; 12-13. Hyperstylus pallipes (13. 8th sternite); 14. Myllocerus griseus; 15. Cyrtepistomus castaneus; 16-18. Arrhaphogaster pilosus (16. distal part of ovipositor; 18. 7 th and 8th sternites); 19. Trachyrhinus sp.; 20. Myosides seriehispidus. 


\section{Accessory gland.}

Accessory gland of spermatheca is always present. A paired accessory gland of vagina is present only in Cleoninae.

\section{ALIMENTARY CANAL}

\section{Proventriculus.}

Proventriculus of Coleoptera has been studies by many authorities. Nüsslin (1912) and Hopkins (1915) reported their excellent studies concerning Curculionoidea with special reference to the family Scolytidae.

In such primitive families as Anthribidae and Attelabidae the proventriculus bears simple setae, which are arranged in 8 or 16 rows. In Brenthidae such simple setae are more closely aggregated together than the above mentioned families and forming 8 rows of setae. In the remaining families, the proventriculus bears blade-like plates, which
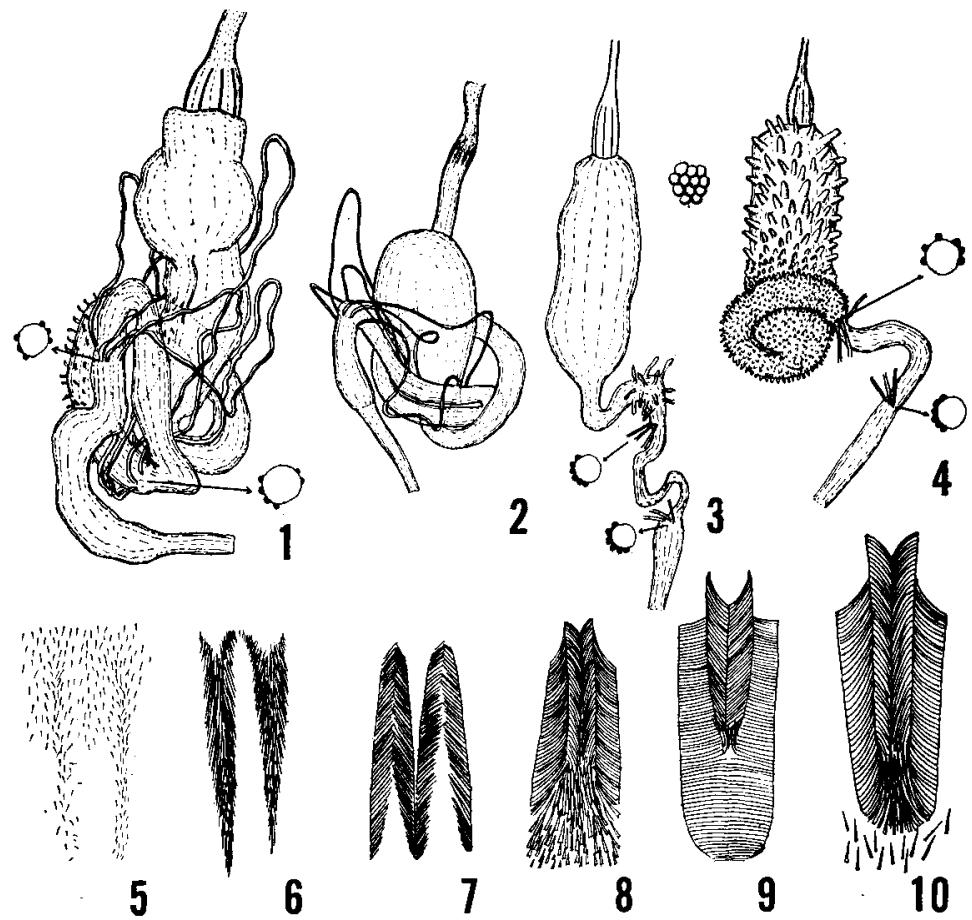

5

6
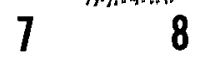

9

10

Fig. XXIV. 1-4: Alimentary canal. 5-10: Proventriculus.

1. Phyllobius rotundicollis; 2. Auletobius uniformis; 3. Hyposipalus gigas;

4. Dryophthoroides sulcatus; 5. Auletobius uniformis; 6. Desmidophorus crassus;

7. Mesalcidodes trifidus; 8. Byrsopages sp.; 9. Niphades variegatus;

10. Pissodes nitidus. 
are forming 8 pairs of rows in various ways. In Mesalcidodes and Mecyslobus (both Mecyslobinae) setae are arranged in Curculionid-type instead of plate.

\section{Ventriculus.}

Concerning the ventriculus I have examined only the presence or absence of the gastric caeca. It is commonly found on the posterior part of the ventriculus in all families and short caecae are found on the whole surface in the Rhynchophoridae, and they are very short and corn-shaped in Hyposipalus gigas.

\section{LARVAF}

Larval studies on the Japanese Curculionoidea will be published before long with the detailed descriptions and some phylogenetic notes.

In this paper a key to the families of Curculionoidea inhaviting in Japan is given below.

1. Hypopharyngeal bracon absent. Antennae with 2 well-developed segments. Terminal segment of maxillary palpus with a few setae. Frontal and epicranial sutures of head indistinct or frontal suture reaching far above antenna. First spiracle on prothorax (Rhynchitinae) or mesothorax (Attelabinae) Attelabidae

$1^{\prime}$. Hypopharyngeal bracon present (excepting Rhynchaeninae). Antennae usually membraneous, with a sensory cone and several setae, not 2 -segmented. Frontal and epicranial sutures usually distinct........2

2. Frontal suture reaching the articulating membrane of mandible. Antennae completely enclosed by a frontal piece........................

2 '. Frontal suture terminating at antenna...................................4

3. Labral rod absent. Mandible usually with mora. Terminal segment of maxillary palpus with a seta. First spiracle on mesothorax. Legs usually discernible Anthribidae

3'. Labral rod present. Mandible without mora. Terminal segment of maxillary palpus without seta. First spiracle on prothorax or intersegmental membrane between pro- and mesothorax. Legs often discernible. Brenthidae

4. Maxillary palpus one-segmented. Pleurum subdivided into two or more lobes. Platy podidae

4'. Maxillary palpus two-segmented......

5. Ocellus absent. Typical segment of abdomen with three dorsal folds, fold I always absent. Scolytidae

5 . Head with one or two pairs of ocelli, one pair on the epicranial piece near antennae, the other, if present, near. the epicranial dorsal seta 5 , ocelli more or less pigmented. Typical segment of abdomen 
often with 4 dorsal folds...............................................6

6. Pleurum subdivided into two or more lobes; if subdivision incomplete, there is a large lobe behind pleurum and epipleurum. Rhynchophoridae

6'. Pleurum not subdivided. Curculionidae

\section{Phylogeny}

The modern views of the phylogeny of the superfamily Curculionoidea were explained by Ting (1936), Emden (1938), Bruhn (1943) and Crowson (1955). Crowson subdivided the Curculionoidea into 9 families, of which $\mathbf{5}$ ones are found in Japan.

In this paper $I$ intend to set forth the phylogenetic system of the Curculionoidea based on the knowledge of the comparative morphology. For this purpose I exert myself to understand the tendency of the differentiation of as many characters as possible.

The examples of progressive differentiation in morphological characters which have been noted by $m e$ in the Curculionoidea may be summerized as follows:

1. Head long to globular.

2. Antennae straight to geniculate.

3. Antennal club loose to compact,

4. Maxillary palpi 4-segmented and flexible to 3-segmented and rigid.

5. Maxillary lacinia distinct to the lacinia and galea connate.

6. Maxillae move horizontally to vertically.

7. Mandibles move horizontally to obliquely.

8. Labial palpi 3-segmented and flexible to the segment less than 3 and rigid.

9. Labial palpi attached to the ventral surface of prementum to the anterior margin of prementum, or to the palpi inserted into cavities on the ventral surface of prementum.

10. Labrum distinct to absent.

11. Metepimera large to invisible.

12. Ninth tergite present to absent in female.

13. Spiracular sclerites present to absent.

14. Male pygidium formed of 7 th tergite to 8 th tergite.

15. Third to 7 th sternites freely articulated to the basal sternites connate.

16. Third-6th sternites similarly articulated to each other, to the 5 th-7th sternites similarly articulated to each other.

17. Tibiae simple to uncinate.

18. Penis with the dorsal and ventral plates of the same size to the dorsal plate absent.

19. Cap-piece of tegmen large and not bilobed to bilobed or absent. 
20. Accessory gland of testis 3 or more paired to 1 or 2 paired.

21. Ovarioles 4-6 paired to 2 paired.

22. Elytra with cost-subcostal trachea located between 10th stria and lateral margin to between 9 th and 10th striae.

23. Anal vein of hind wing divided into 5 branches to no branch.

24. Proventriculus not developed to developed.

Anthribidae may be the most primitive family among the Japanese Curculionoidea having the various primitive characters. The female ovipositor is very conspicuous and has specially adapted to the ovipositing habit.

Attelabidae may be the most related family to Anthribidae having similar mouth organs, male genitalia and abdomen. The most conspicuous characters of Attelabidae are the number of accessory glands of testis, tergal region of abdomen and elytral epipleura. Attelabidae had often been regarded as a group of Curculionidae by many authorities, but it may be a distinct family from the phylogenetic point of view.

Scolytidae including Platypodidae was dropped into a subfamily of Curculionidae by Crowson (1955), but its mouth organ reveals the relation to Anthribid-Attelabid group. Judging from the structure of mough organs it may be presumable that Scolytidae and Platypodidae are specially adapted to the wood-boring habit from the primitive condition. They are similar to Cossoninae in several characters, namely, short head, denticulate tibia and cylindrical body shape, etc. Such characters are, however, commonly found in Bostrychidae and Ciidae and regarded as the parallel adaptation to the wood-boring habit.

Platypodidae may be more primitive than Scolytidae having the freely articulated sternites of abdomen, well-developed spiracular sclerites of tergites and distinct lacinia of maxilla, and further, Platypodidae may fundamentally be separable from Scolytidae by the structure of penis, absence of 9 th sternite in the male and the shape of metendosternite.

Brenthidae, Curculionidae and Rhynchophoridae are very close to each other.

Rhynchophoridae may be somewhat related to the primitive families in the male pygidium and penis, but highly specialized from the other families of Curculionoidea by the small and deeply retructed prementum, male genitalia, ventriculus and antennae. Dryophthorus has been regarded as a genus of Cossoninae, but it should be transferred to Rhynchophoridae. Stromboscerinae is also the member of this family.

Brenthidae s. nov. treated here may be a mixed family of the primitive groups of Curculionidae. Brenthinae has been treated as a distinct family by many authorities, but its mouth organs are similar to those of Cylas and the aedeagus is to that of Apion. Major structures of the larval head may be similar between Brenthinae, Cyladinae, Apioninae and Nanophyinae. Thoracic legs which are short and finely 
segmented are easily observed from the larva of Cylas when dyed. Nanophyinae, though its antennae are geniculate, has apparently close relation to Apioninae in the structures of trochanter, metendosternite, labium, larvae and habit. Desmidophorinae and Ithycerinae are similar to Brenthinae, Cyladinae, Apioninae and Nanophyinae in the structures of proventriculus and aedeagus, and the other characters are close to those of Curculionidae.

Aedeagus of Notaris is apparently Brenthid-type, but the proventriculus is well developed.

The relationship of the families of Curculionoidea of Japan may be illustrated as follows:

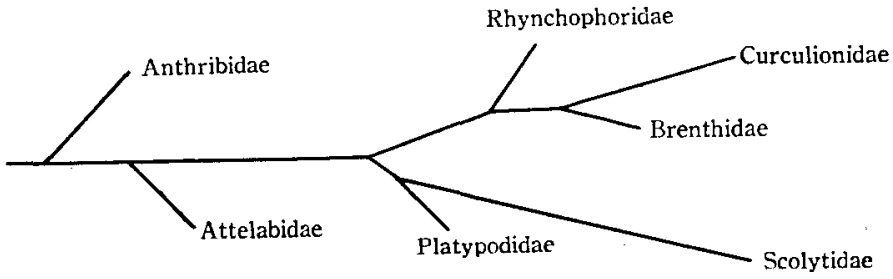

\section{BIBLIOGRAPHY}

Abbott, C. E. 1929. The comparative morphology of the spiracles of two species of weevils. Ann. ent. Soc. Amer. $22: 331-334$.

Anderson, W. H. 1936. A comparative study of the labium of Coleopterous larvae. Smithson. misc. Coll. 95 (13): 29 pp., 8 pls.

Baccio Bacetti 1957. Studi sui Curculionidi italiani. I. Richerche morfologiche, etologiche ed istologiche su Hypera trilineata Marsham. Redia XLII : 61-121, 2 pls.

Bissell, T. L. 1937. Structure of the reproductive system of the pecan weevil. Ann. ent. Soc. Amer. $30: 242-251$.

Blackwelder, R. E. 1934. The prostheca or mandibular appendage. Pan-Pacific Ent. $10: 111-113$.

Blatchley, W. S. \& Leng, C. W. 1916. Rhynchophora or weevils of North East America, $682 \mathrm{pp}$.

Bruhn, F. 1948. The external male genitalia of some Rhynchophora. Great Basin Naturalist $8: 1-35$.

Burke, H. R. 1959. Morphology of the reproductive system of the cotton boll weevil. Ann. ent. Soc. Amer. $52: 287-294$.

Butt, F. H. 1951. Feeding habits and mechanism of the Mexican been beetle. Mem. Cornell agric. Exp. Sta. no. 306, 32pp., 46 figs.

Chararaș, C. 1956. Anatomie et biologie des Coléoptères Curculionides xylophages comparées à celles des Coléoptères Scolytides. Rev. Path. vég. Ent. agr. France XXXV : 113-187, 26 pls.

Chorabik, S. 1952. Anatomy and histology of the digestive canal in the weevil Strophosomus capitatus Deg. (in Polish with English summary). Bull. ent. Pologne 21: 1-29, 17 figs.

Cook, E, F. 1944. The morphology and musculature of the labrum and clypeus of 
insects. Microent. $9: 1-35,18$ figs.

Crowson, R. A. 1938. The metendosternite in Coleoptera: a comparative study. Trans. R. ent. Soc. London 87 : 397-416, 13 pls.

Crowson, R. A. 1944. Further studies on the metendosternite in Coleoptera. Trans. R. ent. Soc. London $94: 273-310,10$ pls, 4 figs.

Crowson, R. A. 1955. Natural classification of the families of Coleoptera, $187 \mathrm{pp}$.

Das, G. M. 1937. The musculature of the mouth-parts of insect larvae. Quart. J. micr. Sci. $80: 39-50$.

Dönges, J. 1954. Der Koph von Cionus scrophulariae L. Zool. Jb. (Anat.) 74: 1-76, 40 figs.

Dundlich, E. 1923. Ueber die Sturidulation von Lepyrus capucinus Schall. Ent. Blätt. 19: $93-94$.

Du Port, E. M. 1946. Observations on the morphology of the face in insects. J. Morph. 79: 371-417, 7 pls.

Ehara, S. 1954. Comparative anatomy of male genitalia in some Cerambychid beetles. J. Fac. Sci. Hokkaido Univ. VI. Zool. 12:61-115.

Fenili, G. A. 1952. Contributo alla conoscenza dell Attelabus nitens Scop. Redia 37: $195-281$.

Fiori, G. 1954. Morfologia abdominale, anatomia ed istologia degli apparati genitali di Pimelia angulata confalonierii Grid. (Col. Tenebrionidae) e formazione dello spermatoforo. Boll. Ist. Ent. Univ. Bologna 20:377-422, 21 figs.

Ferris, G. F. 1940. The myth of the thoracic sternites of insects. Microent. 5: $87-90$.

Ferris, G. F. 1942. The basic materials of the insect cranjum. Microent, 8: 1-24, 6 figs.

Ferris, G. F. 1947. The contradictions of the insect head. Microent. 12: 59-64.

Forbes, W. T. M. 1922. The wing-venation of the Coleoptera. Ann. ent. Soc. Amer. $15: 328-345,7$ pls.

Forbes, W. T. M. 1926. Wing-folding patterns of Coleoptera. J. N. Y. ent. Soc. 24 : $42-68,91-139$.

Frediani, D. 1952. Contributo alla conoscenza del Rhynchites bacchus L. Boll. Lab. Ent. Agr. Silvestri, Portici XI : 109-148, 28 pls.

Hiznay, P. A. \& Krause, J. B. 1955. The structure and musculature of the larval head and mouth-parts of the horned passalus beetles, Popilus disjunctus Illiger. J. Morph. $97: 55-70,2$ pls.

Hopkins, A. D. 1913. Parallelism in morphological characters and physiological characters in Scolytid beetles. Proc. biol. Soc. Washington XXVI: 209-212.

Hopkins, A. D. 1915. Contributions toward a monograph of the Scolytid beetles. II. Preliminary classification of the Superfamily Scolytoidea. U. S. Dep. Agr., Tech. Ser. no. 17, part $11: 165-232$.

Hundertmark, A. 1935. Die Entwicklung der Flügel der Mehlkäfers Tenebrio molitor, mit besonderer Berücksichtigung der Häutungsvorgänge. Z. Morph. Oekol. Tiere $30: 506-543$, 21 figs.

Jeannel, R. \& Paulian, R. 1944. Morphologie abdominale des Coléoptères et systematique de l'ordre. Rev. fr. Ent. XI : 65-110.

Kleine, R. 1919. Die Stridulationsapparat der Gattung Liparus Oliv. Arch. Naturg. Abt. A, 83, Heft 12:54-68, 1 pl. (1917)

Knab, F. 1915. The secretions employed by Rhynchophorous larvae in cocoon-making. Proc. ent. Soc. Washington $17: 154-158$.

Kolbe, W. 1927. Ueber die Mandibelanhange bei den Curculioniden. Z. Ent. 15 (4): 
1-3.

Kühne, O. 1915. Der Tracheenverlauf in Flügel der Koleopteren-nymphe. Z. wiss. Zool. 112 : $602-718,2$ pls.

Lacordaire, T. 1863, 66. Genera des Coléoptères. VI, VII. $637 \& 620$ pp.

Leconte, J. \& Horn, H. 1876. The Rhynchophora of America, Nortin of Mexico. Proc. Amer. Philos. Soc. XV (96), 455 pp.

Lenkowa, A. 1949. The structure of the female reproductive organs in some gonohorrhistic and parthenogenetic species of the genus Polydrosus Germ. Bull. int. Acad. Cracovie 1949: 447-484.

Lenkowa, A. 1957. Specific differences in the structure of the female reproductive organs of the genus Polydrosus Germ. Bull. ent. Pologne XXVI: 41-71.

Lindroth, C. H. 1957. The principal terms used for male and female genitalia. Opusc. Ent. XXII : 241-256.

Linson, L. 1937. Le système malpighien de Araeocerus fasciculatus Degeer, avec quelque remarques sur la valeur phylogenetique des systèmes malpighens cryptosolenies. Ann. Soc. R. Zool. Belg. LXVIII : 103-120.

McClenhan, E. M. 1904. The development of the rostrum in Rhynchophorous Coleoptera. Psyche 11: 89-104, 4 pls.

Mazzi, V. \& Baccetti, B. 1956. I tubi Malpighiani e la secrezione della seta nelle larve di Donus crinitus Boheman. Redia XLI : 315-340, 5 pls.

Metcalf, M. E. 1932. The structure and development of the reproductive system in the Coleoptera with notes on its homologies. Quart. J. mirc. Sci. (N. S.) 75 : 49-129.

Muir, F. 1918. On the mechanism of the male genital tube in Coleoptera. Trans. R. ent. Soc. London 1918: 404-414.

Muir, F. 1918. Notes on the ontogeny and morphology of the male genital tube in Coleoptera. Trans. R. ent. Soc. London 1918:223-229.

Needham, J. G. 1906. The maxilla in Rhynchophorous Coleoptera. Psyche 13:76.

Nunberg, M. 1928. Die Morphologie der Larven- und Imagines-Mundwerkzeuge der Borkenkäfer. Polsk. Pismo Ent. VII : 137-171.

Nüsslin, O. 1911-12. Phylogenie und System der Borkenkäfern. Naturw. Z. f. Forst u. Landw. 1911: 1, 47, 109, 145, 248, 271, 300, 372. Z. wissenschaft. Insektenbiol. VII/VIII : $19,51,81,125,162,205$ (1912)

Pesson, P. \& Hararas, C. 1955. Contribution à l'anatomie microscopique du tube digestif de Rhyncholus porcatus Germ. et Rhyncholus elongatus Gyll. Rev. Path. vég. Ent. Agr. France XXXIV: 218-228.

Phelps, R. J. 1956. A contribution to the morphology of Piezotrachelus varium (Wagner), with observations on that of Apion (Conapion) chirindanum Wagner. J. ent. Soc. S. Afr. 19: 143-191, 29 figs.

Poll, M. 1932. Contribution à l'étude des tubes de Malpighi der Coléoptères. Rec. Inst. Zool. Torley-Rousseau 4:47-80, 19 figs.

Reichenback-Klinke, H. H. 1952. Die Rectalpapillen der Insekten, insbesondere der Käfer, und ihre Bezeichungen zur Stammensgesichte. Zool. Jb. Anat. 72: 231250.

Reichenback-Klinke, H. H. 1952. Der Darmkanal der Coleopteren als Kriterium für stammensgeschichtliche Untersuchungen. Verh. dtsch. zool. Ges. Leipzig 1952: $461-467,2$ figs.

Reichenback-Klinke, H. H. 1953. Die Entwicklung des Proventrikels der Coleopteren mit besonderer Berücksichtigung der carnivoren Arten der Unterordung Polyphaga. Ent. Blätt, 49;2-17. 
Reichenback-Klinke, H. H. 1953. Der Kaumagen holzfrassender Käfer. Z, angew. Ent. $34: 335-345$.

Sharp, D. 1918. Studies in the Rhynchophora. IV. A preliminary note on the male genitalia. Trans. R. ent. Soc. London 1918: 209-222.

Sharp, D. \& Muir, F. 1912. The comparative anatomy of the male genitalia in Coleoptera. Trans. R. ent. Soc. London 1912: 477-642.

Sing-Pruthi, H. 1924. On the post-embryonic development and homologies of the male genital organs of Tenebrio molitor L. Proc. zool. Soc. London 1924: 857868.

Snodgrass, R. E. 1931. Morphology of the insect abdomen. I. General structure of the abdomen and its appendages. Smithson. misc. Coll. 85 (6), 128 pp., 46 figs.

Snodgrass, R. E. 1933. Morphology of the insect abdomen. II. The genital ducts and the ovipositor. Smithson. misc. Coll. 89 (8), 148 pp., 48 figs.

Snodgrass, R. E. 1935. Principles of Insect Morphology, $667 \mathrm{pp}$.

Snodgrass, R. E. 1936. Morphology of the insect abdomen. III. The male genitalia. Smithson. misc. Coll. 94 (14), 96 pp., 29 figs.

Snodgrass, R. E. 1947. The insect cranium and the 'epicranial suture'. Smithson. misc. Coll. $107(7), 52 \mathrm{pp}$.

Stickney, F. S. 1923. The head-capsule of Coleoptera. Illinois Biol. Monograph 8: 1-104, 26 pls.

Stammer, H. J. 1934. Bau und Bedeutung der malpighischen Gefässe der Coleopteren. Z. Morph. Oekol. Tiere 29 : 196-217, 47 figs.

Strenger, A. 1952. Die functionelle und morphologische Bedeutung der Nähte am Insektenkopf. Zool. Jb. A nat. 72: 468-521, 8 figs.

Tanner, V. 1927. A preliminary study of the genitalia of female Coleoptera. Trans. Amer. ent. Soc. $53: 5-50,14 \mathrm{pls}$.

Thiel, H. 1936. Vergleichende Untersuchungen an den Vormagen von Käfern. Z. wiss. Zool. $147: 395-432,26$ figs.

Ting, P. C. 1933. Feeding mechanisms of weevils, their function and relationship to classification. Calif. Dep. Agr., Month. Bull. 22 : 161-165.

Ting, P. C. 1936. The mouth parts of the Coleopterous group Rhynchophora. Microent. I : 93-114, fig. $75-82$.

Tower, W. L. 1903. The origin and development of the wings of Coleoptera. Zool. Jb. $70: 517-572,20 \mathrm{pls}$.

Whitehead, W. E. 1932. The morphology of the head-capsule of some Coleopterous larvae. Canad. J. Res. 6: 227-252.

Wilcox, J. \& Baker, W. M. 1935. The deciduous cusps of the Alophini. Bull. Brooklyn ent. Soc. $30: 20-21$.

Williams, I. W. 1938. The comparative morphology of the mouth parts of the order Coleoptera treated from the standpoint of phylogeny. J. N. Y. ent. Soc. 46 : 245-288, 11 pls.

Williams, J. L. 1945. The anatomy of the internal genitalia of some Coleoptera. Proc, ent. Soc. Washington $47: 73-87,4 \mathrm{pls}$. 